\title{
UPAYA HUKUM DALAM PENYELESAIAN SENGKETA PENCEMARAN LINGKUNGAN LAUT DALAM KASUS TUMPAHAN MINYAK MONTARA DI LAUT TIMOR
}

\author{
Oleh: \\ Ni Putu Suci Meinarni ${ }^{1}$
}

\begin{abstract}
Diplomacy as a means of communication made by various parties, including the negotiations between representations who have been recognized or defined as well as the negotiations when it was not possible to see a bright spot, the one party or two countries who consider necessary, can choose the path of another in the settlement of disputes. Regarding the case Montara, Indonesia can choose the legal path is through ITLOS. When all lanes closed negotiations and diplomacy, international legal channels under the umbrella of ITLOS is open for the settlement of cases of oil spills in the Montara platform. If ITLOS considered too early to have as a line dispute resolution, since the country rarely choose ITLOS as a settlement of the dispute, as evidenced since it entry into force (between 1994 to 2006), only 13 cases were handled by ITLOS, and in UNCLOS itself is possible for more flexible judicial selection and Arbitration still in the high demand.
\end{abstract}

Keywords: diplomacy, UNCLOS,ITLOS, Arbitration, Montara.

\begin{abstract}
Abstrak
Diplomasi sebagai suatu cara komunikasi yang dilakukan oleh berbagai pihak termasuk negosiasi antara wakil-wakil yang sudah diakui atau yang diartikan pula sebagai perundingan-perundingan ketika sudah tidak memungkinkan lagi untuk menemui titik terang maka salah satu pihak maupun kedua negara yang menganggap perlu, dapat memilih jalur lain dalam penyelesaian sengketa. Berkaitan dengan kasus Montara, indonesia dapat memilih jalur hukum yaitu melalui ITLOS. Bila semua jalur negosiasi dan diplomasi tertutup, jalur hukum internasional di bawah payung hukum ITLOS terbuka untuk penyelesaian kasus tumpahan minyak di sumur Montara. Apabila ITLOS dianggap terlalu dini untuk dipilih sebagai jalur penyelesaian sengketa, karena memang negara jarang sekali memilih ITLOS sebagai tempat penyelesaian sengketa, terbukti sejak entry into force (antara tahun 1994 sampai dengan tahun 2006), hanya 13 kasus yang ditangani ITLOS. Di dalam UNCLOS masih memungkinkan adanya pilihan peradilan yang lebih fleksibel dan lebih dinikmati oleh negara-negara yaitu Arbitrase.
\end{abstract}

Kata kunci: diplomasi, UNCLOS, ITLOS, Arbitrasi, Montara.

1 Penulis adalah Dosen STIMIK-STIKOM Indonesia, Jl. Tukad Pakerisan No. 97, Denpasar, Bali, email:sucimeinarni@gmail.com 


\section{PENDAHULUAN}

Pada tahun 1982, Perserikatan Bangsa-Bangsa dalam United Nations Convention on Law of the Sea 1982 (UNLOS 1982) Pasal 1 ayat (4), mendefinisikan pencemaran laut sebagai :

"Pollution of the marine environtment" means the introduction by man directly, or indirectly, ofsubstancesorenergy into the marine environtment, including estuaries, which results or is likely to result in such deleterious effects as harm to living resources and marine life, hazards to human health, hindranceto marine activities, including fishing and other legitimate uses of the sea, impairment of quality for use of sea water and reduction of amenities. $^{2}$

Ada dua kriteria yang digunakan untuk mengklasifikasikan sumber pencemaran, yaitu: berdasarkan aktivitas penyebab terjadinya pencemaran (aktivitas dasar laut, dumping, navigasi) dan berdasarkan cara polutan masuk ke dalam lingkungan (polusi dari daratan dan polusi atmosferik). ${ }^{3}$

Pada tahun 2009, Indonesia mengalami kasus pencemaran lingkungan laut, yang pada akhirnya

2 Konvensi Perserikatan Bangsa-bangsa tentang Hukum Laut, Departemen Luar Negeri Direktorat Perjanjian Internasional.

3 Budislav Vukas, 2004, The Law of the Sea, Leiden, Martinus Nijhoff Publishers, hlm. 236-237. berujung pada sengketa dengan pihak swasta yang terkait dengan pencemaran tersebut.Tanggal 20 Agustus 2009', telah terjadi ledakan di ladang minyak Montara yang berada di kawasan Zona Ekonomi Ekslusif (ZEE) Australia. Ledakan tersebut mengakibatkan tumpahnya minyak mentah yang meluas sampai kepada wilayah ZEE Indonesia.

Ledakan ladang minyak Montara menjadi kasus luapan minyak terbesar yang terjadi di ladang minyak Montara di Laut Timor, yang terletak di pantai utara Australia. Ladang minyak Montara terletak di pantai Kimberley, $250 \mathrm{~km}$ di utara Truscott, dan 690 km di barat Darwin ${ }^{5}$. Kasus ini merupakan salah satu bencana minyak terbesar yang dialami Australia.Aliran minyak terjadi sejak 21 Agustus 2009 dan berlanjut hingga 3 November 2009. Kedutaan Besar Australia di Jakarta menjelaskan bahwa minyak mentah mulai mengalir menuju Laut Timor pada tanggal 21 Agustus 2009, dan memberikan notifikasi kepada Pemerintah Indonesia setelah diperoleh citra satelit pada tanggal 1 September 2009 yang menunjukkan bahwa tumpahan minyak mengalir menuju ZEE Indonesia dalam bentuk gumpalan ${ }^{6}$. Sebagai langkah lanjutan, pada tanggal 28 Oktober 2009, the Minister for the Environment, Heritage and the Arts, Peter Garrett,

\footnotetext{
4 Wikipedia,Montara Oil Spill, www.wikipedia com. Diakses tanggal 12 Juni 2010

5 Ibid

$6 \quad$ Ibid
} 
menjelaskan secara langsung kepada Menteri Lingkungan Indonesia, Gusti Muhammad Hatta, terkait dengan permasalahan tumpahan minyak Montara. $^{7}$

Kerugian ditimbulkan oleh tumpahan minyak mencemari kawasan laut Indonesia, Australia, dan Timor Leste.Negara Republik Indonesia cukup besar.Pemerintah Indonesia bersama-sama dengan Australia bertanggungjawab dalam memelihara dan memberikan perlindungan terhadap lingkungan. Salah satu langkah yang ditempuh untuk dapat menyelesaikan kasus pencemaran minyak ini, Pemerintah Indonesia mengajukan perkara pencemaran laut tersebut ke dalam sengketa dengan PTTEP Australasia.

Berdasarkan latar belakang diatas, maka penulis tertarik untuk memaparkan mengenai bagaimanakah penyelesaian sengketa yang dapat ditempuh dalam kasus minyak Montara?

Tujuan Penelitian ini secara obyektif adalah;

Untuk mengetahui pola penyelesaian sengketa dalam hukum internasional yang ditempuh dalam kasus pencemaran lingkungan laut oleh tumpahan minyak di laut Timor.

Dan secara subyektif adalah:

Untuk memperoleh tambahan pengetahuan di bidang hukum internasional khususnya yang berkaitan

7 Australia Embassy Indonesia, Montara Oil Spill, Media Release, 2 November 2009. Jakarta. dengan penyelesaian sengketa pencemaran minyak.

\section{METODE PENELITIAN}

\section{1 Sifat Penelitian}

Spesifikasi penulisan mengenai sengketa antara Indonesia dan Australia yang juga sebagai korban dalam Kasus Minyak Montara di Laut Timor, yang termasuk dalam ZEE Indonesia, serta tantangan yang dihadapi terkait dengan belum adanya rezim hukum yang sesuai dengan penyelesaian sengketa, adalah merupakan penelitian mormatifempiris, yang sifatnya deskriptif.

Penelitian normatif diartikan sebagai penelitian yang mencakup ilmu kaidah dan ilmu pengertian atau yang biasa disebut ilmu dogmatik hukum (normwissenschaft) ${ }^{8}$. Sedangkan penelitian hukum empiris adalah jenis penelitian yang dilakukan terutama dengan cara meneliti data primer9. Sehingga, penelitian hukum normatifempiris adalah penelitian hukum yang menggunakan data primer.

\section{2 Jenis Penelitian}

Dalam penelitian sumber data penelitian diperoleh tidak hanya dari data primer melainkan dari data sekunder.Data yang bersumber dari data primer adalah data yang diperoleh langsung dari pihak yang menghayati data tersebut ${ }^{10}$ atau data yang diperoleh

8 Sugeng Istanto, 2004, Bahan Kuliah Politik Hukum (Diktat Magister Hukum Program Pascasarjana UGM), Yogyakarta, hlm 71-72

9 Soerjono Soekanto \& Sri Mamudji, 2003, Penelitian Hukum Normatif Suatu Tinjauan, Jakarta, PT. Radja Grafindo Persada, hlm.1314

10 Sugeng Istanto, Loc. Cit. 
secara langsung dari lapangan yang merupakan hasil informasinarasumber, yaitu dari instansi terkait.

Adapun bahan-bahan hukum yang dijadikan objek penelitian kepustakaan dibagi menjadi tiga macam, yaitu bahan hukum primer, bahan hukum sekunder dan bahan hukum tersier. ${ }^{11}$

Bahan hukum primer, sebagai bahan yang mengikat, terdiri dari sejumlah peraturan internasional maupun nasional, meliputi:

a. Piagam Perserikatan BangsaBangsa (PBB),

b. Konvensi Hukum Laut Internasional (UNCLOS 1982),

c. Konvensi-konvensi internasional, regional, dan bilateral yang berkaitan dengan lingkungan dan kelautan.

Bahan hukum sekunder, adalah bahan hukum yang memberikan penjelasan mengenai bahan hukum primer, terdiri dari buku-buku, jurnal, makalah, surat kabar, karya ilmiah para sarjana hukum, dan berbagai bahan yang ditulis di internet (website) yang berkaitan dengan permasalahan.

Bahan hukum tersier meliputi seluruh referensi yang memberikan petunjuk atau penjelasan atas bahan hukum primer dan sekunder, misalnya: kamus hukum, kamus bahasa Indonesia, kamus bahasa Inggris, dan sebagainya.

\section{3 Alat Pengumpulan Data}

Mengingat bidang penelitian

11 Soerjono Soekanto. Op Cit.hlm. 52 ini,yaitu penelitian dibidang hukum, peneliti menggunakan instrumen pengumpulan data berupa: wawancara, observasi, dan studi dokumen ${ }^{12}$. Data yang bersumber dari data sekunder, sebagaimana umumnya dalam penelitian normatif atau kepustakaan, juga digunakan sebagai alat pengumpulan data. ${ }^{13}$

\section{4 Tahapan Penelitian}

\section{a. Tahap Persiapan}

Tahap ini dimulai dengan mengumpulkan bahan atau data tentang permasalahan dalam penulisan ini, dan selanjutnya menyusun usulan penelitian, melakukan konsultasi dan penyempurnaan, mengadakan wawancara dan mengurus perijinan.

\section{b. Tahap Penelitian}

Tahap ini dilakukan dengan wawancara narasumber dan penelitian terhadap kepustakaan yang berkaitan dengan permasalahan dalam penelitian ini, dengan maksud untuk mengumpulkan data dan melakukan pengkajian lebih lanjut terhadap data sekunder yang berupa pengumpulan dankajian atau analitis lebih lanjutyang lebih mendalam terhadap bahan hukum primer, sekunder dan tersier. sedangkan penelitian lapangan dilakukan dengan cara mengadakan wawancara dengan narasumber atau pihak yang berkaitan dengan permasalaahan penelitian ini sehingga dapat memberikan data atau keterangan yang akurat.

12 Ibid. hlm. 66

13 Maria Sumarjono, 2001, "Pedoman Pembuatan Usulan Penelitian”, Jakarta, Gramedia Pustaka Utama, hlm. 36 


\section{c. Tahap Penyelesaian}

Tahap ini merupakan tahap akhir dari seluruh rangkaian kegiatan penelitian denganmelakukan penulisan laporan awal sebagai hasil penelitian dengan cara menganalisis, kemudian dilanjutkan dengan konsultasi dan revisi serta diakhiri dengan pembuatan penulisan laporan penelitian.

\section{5 Pengolahan dan Analisis Data}

Padapenelitianini,penyajianhasil penelitian (sebagai hasil pengolahan data) disatukan dengan analisis data ${ }^{14}$. Artinya penulis kemudian melakukan analisa secara detail dan sistematis terhadap setiap sumber yang didapat, dilakukan perbandingan secara secara menyeluruh dan kualitatif, sehingga menghasilkan sebuah penulisan yang tepat dan mencapai tujuan penulisan yang diinginkan.

\section{6 Hambatan Penelitian}

Peneliti membutuhkan waktu yangtidaksingkatuntukmenyelesaikan seluruh proses penelitian karena minimnya literatur yang dimiliki dan kerumitan proses birokrasi dari pihakpihak yang terkait dengan penelitan. Penulis juga dihadapkan dengan situasi dimana permasalahan yang diangkat masih dalam proses sehingga akan terdapat banyak sekali data-data terbaru yang artinya akan mempengaruhi waktu dan proses penulisan berkaitan dengan kemungkinan munculnya permasalahan baru yang berimbas pada penambahan analisis atau penggunaan lebih banyak lagi teori hukum.

14 Ibid.hlm. 68.

\section{7 Cara Mengatasi Hambatan dalam Penelitian}

Hingga kini, penulis berusaha menyikapi hambatan penelitian dengan cara melakukan pencarian informasi secara intensif melalui media maupun sumber-sumber lain guna melengkapi hasil penulisan.

\section{HASIL DAN PEMBAHASAN}

Pembahasan terhadap hasil penelitian dan pengujian yang diperoleh disajikan dalam bentuk uraian teoritik, baik secara kualitatif maupun kuantitatif. Hasil percobaan sebaiknya ditampilkan dalam berupa grafik atau pun tabel. Untuk grafik dapat mengikuti format untuk diagram dan gambar.

\subsection{Penyelesaian Sengketa Kasus Pencemaran Minyak Platform Montara}

Ketika area suatu lingkungan telah termasuki oleh sesuatu zat yang asing atau tidak orisinil berasal dari tempat tersebut, dapat dikatakan wilayah lingkungan tersebut telah tercemar atau terkontaminasi. Tercemar sendiri mengundang banyak pengertian di berbagai kalangan akademisi, Thomas M. Pankratz salah satunya mengartikan, Pollution is the presence of pollutant in the environment. ${ }^{15}$

Tanah, air dan udara merupakan tiga elemen penting pada lingkungan. Ketiga elemen tersebut merupakan

15 Thomas M. Pankratz 2001, Environmental Engineering Dictionary and Directions, Lewis Publishers, United States, hlm. 194. 
objek dari hukum lingkungan.Salah satu elemen penting yang tidak dapat dilepaskan dari kehidupan kita dengan fungsi yang sangat vital serta berkaitan dengan penulisan ini adalah "Air". Pencemaran air.

Penyebab tercemarnya air dapat dikatagorikan sebagai berikut $:^{16}$

\section{Organic Pollutant}

Termasuk di dalamnya adalah sampah rumah tangga, pestisida, limbah pertanian, minyak, sampah-sampah dari pengolahan bahan makanan, limbah pabrik kertas, dan lain-lain.

\section{Inorganic Pollutant}

Kelompok sampah ini terdiri dari garam anorganik, asam mineral, logam, deterjen, dan lain-lain.

\section{Sediments}

Erosi tanah sebagai proses alamiah yang membuat endapanendapan pada air. Sedimentasi dari tanah banyak terbawa oleh air menuju sungai, danau, dan laut. Beberapa unsur material yang juga ikut terbawa arus air dalam proses sedimentasi alami adalah seperti, tembaga, nikel, mangan, kromium dan molibdenum.

\section{Radioactive Materials}

Polusi radioaktif disebabkan oleh proses pertambangan dan produksi substansi radioaktif, penggunaan radioaktif material untuk pembangkit listrik

16 Anil Kumar De, 2009, Environment and Ecology, New Age International, India, hlm. 65-68. tenaga nuklir, penggunaan isotop radioaktif dalam dunia kedokteran, berbagai industri dan riset ilmiah serta percobaan nuklir. Hasil pembuangan limbah nuklir ke media air sangat berbahaya pada masa yang akan datang.

\section{Thermal Pollutants}

Batubara atau bahan bakar nuklir pembangkit listrik berbahan bakar termal adalah sumber polusi termal. Air panas dari pembangkit ini dibuang sebagai limbah ke dalam danau atau sungai terdekat di mana suhu meningkat sekitar 10 derajat celcius. Efek ini berbahaya pada kehidupan air di badan air.

Pencemaran lingkungan laut merupakan salah satu pokok bahasan dalam Perserikatan Bangsa-Bangsa (PBB).UNCLOS 1982 merupakan produk hukum PBB yang mengatur masalah-masalah terkait dengan lingkungan laut. Berikut adalah definisi pencemaran lingkungan laut menurut Pasal 1 ayat (4) UNCLOS 1982:

"Pollution of the marine environtment" means the introduction by man directly, or indirectly, ofsubstancesorenergy into the marine environtment, including estuaries, which results or is likely to result in such deleterious effects as harm to living resources and marine life, hazards to human health, hindranceto marine 
activities, including fishing and other legitimate uses of the sea, impairment of quality for use of sea water and reduction of amenities. ${ }^{17}$

Secara khusus, pencemaran laut dapat dibedakan dalam lima kategori utama, yaitu : ${ }^{18}$

1. Marine pollution caused via the atmosphere by land based activities.

Bukti-bukti ilmiah menunjukkan adanya tiga penyebab utama pencemaran laut golongan pertama ini, yaitu:

a. Penggunaan berbagai macam "synthethic chemicals" khususnya "chlonarinated hydrocarbons" untuk pertanian

b. Pelepasan logam-logam berat ("heavy metal") seperti merkuri akibat proses industri atau lainnya

c. Pengotoran atmosfer oleh hydrocarbons minyak yang dihasilkan oleh penggunaan minyakbumiuntukmenghasilkan energi.

2. The disposal of domestic and industrial wastes.

Pencemaran yang disebabkan oleh pengaliran limbah domestik atau limbah industri dari pantai, baik dari sungai, "sewage outlets" atau akibat "dumping".

17 Pasal 1 ayat (4) UNCLOS

18 Melda Kamil Ariadno, 2007, Hukum Internasional Hukum Yang Hidup, Jakarta, Diadit Media, hlm. 24.
3. Marine pollution caused by radioactivity.

Pencemaran laut karena adanya kegiatan-kegiatan radioaktif alam maupun ataupun kegiatankegiatan manusia.Dua penyebab utamanya adalah percobaan senjata nuklir dan pembuangan limbah radioaktif, termasuk pencemaran yang disebabkan oleh penggunaan laut untuk kepentingan militer atau pembuangan alat-alat militer di laut.

4. Ship-borne pollution.

Pencemaran jenis ini dapat terdiri dari berbagai macam bentuk kapal dan muatan. Akan tetapi penyebab utamanya adalah tumpahan minyak di laut, yang dapat dibedakan karena kegiatan kapal seperti pembuangan air ballast atau karena adanya kecelakaan kapal di laut, terutama apabila kecelakaan itu melibatkan kapal tanker.

5. Pollution from offshore mineral production.

Kegiatan penambangan di dasar laut, terutama apabila terjadi kebocoran pada instalasi penambangan dan pembuangan limbah yang tidak memenuhi persyaratan yang telah ditentukan.

Dalam penelitian ini, kasus yang menjadi objek dalam pembahasan adalah kasus pencemaran minyak di laut. Pelu diketahui bahwa secara 
umum, pencemaran minyak di laut berasal dari beberapa sumber: ${ }^{19}$

1. Tumpahan minyak karena operasional kapal dan kecelakaan kapal

2. Pelimpasan minyak dari darat (down the drain)

3. Terbawa asap (up in smoke)

4. Eksplorasi dan eksploitasi lepas pantai

5. Pipa transportasi minyak

6. Tank cleaning

7. Perembesan alami (natural seeps)

Pencemaran lingkungan laut oleh minyak dapat menimbulkan dampak negatif terhadap sumber daya hayati dan nonhayati, sebagai berikut: ${ }^{20}$

1. Dampak terhadap sumber daya nonhayati

Minyak dapat merusak sumbersumber kekayaan nonhayati, seperti:

a. Air permukaan dan air bawah tanah (paling mudah tercemar oleh tumpahan minyak)

b. Sedimen dan tanah (seringkali tercemar karena adanya kontak langsung maupun tidak langsung)

c. Udara (bahaya penguapan benzene, karenamempunyai efek karsinogenik)

d. Benda purbakala (seperti cagar alam dan harta karun di dasar laut dianggap dapat mengurangi nilai estetikanya)

19 Eny Budi Sri Haryani, Makalah Pribadi Pengantar falsafah sains, IPB, Bogor, 2005.

20 Ibid.
2. Dampak terhadap sumber daya hayati

Minyak dapat merusak sumbersumber kekayaan yang dapat terbarui, yaitu:

a. Biota, semua biota dapat terkena dampak tumpahan minyak seperti pada kelompok mamalia laut, ikan, plankton dan/atau jasad renik, reptilia, mollusca, crustaceae dan invertebrata lainnya serta burung yang hidup di sekitar laut.

b. Kerusakan juga dapat terjadi pada ekosistem, yaitu:

1) Terumbu karang (dampaknya sangat mematikan/lethal dan sub-lethal, misalnya pengurangan kemampuan reproduksi, perkembangan larva dan kolonisasi, laju pertumbuhan, kemampuan fotosintesa, struktur sel dan kemampuan makan).

2) Mangrove (berdampak pada pertumbuhan mangrove yang dan organisme lainnya yang berasosiasi pada mangrove).

3) Padang Lamun, Rumput Laut, dan Vegetasi bawah air lainnya (mempengaruhi vegetasi yang berfungsi sebagai kawasan asuhan, mencari makan dan berlindung berbagai spesies penting) 
4) Kawasan mempengaruhi berbagai daerah penangkapan ikan seperti daerah perikanan sensitif (sensitif terhadap gangguan lingkungan), daerah penangkapan ikan (wilayah yang sudah ditentukan sebagai daerah penangkapan ikan) dan daerah jalurjalur penangkapan ikan dan wilayah pengelolaan perikanan.

3. Dampak terhadap sosial ekonomi masyarakat

Tumpahan minyak memiliki pengaruh yang besar terhadap perikanan budidaya, pembenihan (hatchery) budidaya biota laut dan air payau, tambak garam, perikanan tangkap dan pariwisata.

Pencemaran akibat tumpahan minyak adalah masalah utama pada beberapa perairan pantai, membunuh atau berdampak pada ikan, organisme laut lainnya, burung dan mamalia. Tumpahan minyak juga membunuh atau mengurangi kehidupan organisme di pasir pantai maupun karang, dan juga dapat membunuh cacing-cacing dan serangga yang merupakan makanan bagi burung maupun satwa liar.Ketika tumpahan menyusup ke rawa-rawa pesisir, minyak dapat merusak atau membunuh ikan, udang, dan hewan lainnya brids.

Tumpahan minyak juga dapat mengotori pantai digunakan untuk berenang dan rekreasi.meskipun kadang-kadang kerusakan yang menghebohkan yang disebabkan oleh tumpahan minyak, mereka dipandang sebagai masalah yang relatif kecil untuk ikan dan lingkungan laut dibandingkan dengan pencemaran nutrisi kronis. tergantung pada jumlah dan jenis tumpahan minyak, di mana ia tumpah, dan kondisi cuaca, pemulihan ekosistem dapat cepat atau sangat lambat. $^{21}$

\subsection{Intrumen \\ Hukum \\ Internasional Mengenai \\ Lingkungan dan Lingkungan \\ Laut}

Akomodasiterhadapkepentingan Indonesia dan juga dunia internasional atas perlunya eksistensi rezim hukum laut telah dilakukan melalui usahausaha untuk memperoleh rezim hukum laut yang menyeluruh, yaitu sebagaimana yang tercantum dalam beberapa konvensi mengenai hukum laut, antara lain :

1. Konferensi Kodifikasi Den Haag 1930 (The Hague Codification Conference in 1930) di bawah naungan Liga Bangsa-Bangsa.

2. Konferensi PBB tentang Hukum Laut I tahun 1958 (The First UN Conference on the Law of the Sea in 1958).

3. Konferensi PBB tentang Hukum Laut II tahun 1960 (The Second UN Conference on the Law of the Sea in 1960).

21 Marquita K. Hill, 2004, Understanding Environmental Pollution $2^{\text {nd }}$ Edition, Cambridge University Press, United Kingdom, hlm. 206. 
4. Konferensi Hukum Laut III tahun1982 (The Third UN Conference on the Law of the Sea 1982)yang menghasilkan United Nations Convention on the Law of the Sea (UNCLOS 1982).

UNCLOS 1982 merupakan upaya dunia internasional atas pembentukan rezim hukum laut menyeluruh yang disetujui di Montego Bay, Jamaica, pada tanggal 10 Desember 1982 beranggotakan 164 Negara. $^{22}$ UNCLOS 1982 terdiri dari 17 bagian dan 9 lampiran yang antara lain mengatur tentang: batasbatas dari yurisdiksi nasional di ruang udara di atas laut, navigasi, riset ilmiah, pertambangan laut, eksploitasi sumber hayati dan non hayati di laut, perlindungan dan pemeliharaan laut serta penyelesaian perselisihan atas eksploitasi dan eksplorasi laut oleh negara-negara peserta.

Sesuai dengan UNCLOS 1982 Pasal 194, Negara-negara harus mengambil segala tindakan yang perlu, baik secara individual maupun bersama-sama untuk mencegah, mengurangi, dan mengendalikan pencemaran lingkungan laut yang disebabkan oleh setiap sumber dengan menggunakan cara-cara praktis yang sesuai dengan kemampuan masing-

22 United Nation Division for Ocean Affairs and The Law of The Sea Chronological lists of ratifications of, accessions and successions to the Convention and the related Agreements, http://www.un.org/Dept/los/reference_files/ chronological list_of ratifications.htm, Diakses pada 7 Oktober 2012 masing. Setiap kegiatan yang berada di bawah yurisdiksi Negara-negara tersebut harus dilakukan dengan cara sedemikian rupa sehingga tidak mengakibatkan kerusakan yang diakibatkan oleh pencemaran kepada Negara-negara lain dan lingkungannya. Apabila terjadi pencemaran, tiap Negara harus melakukan upaya agar pencemaran yang timbul dari tindakantindakan dan kegiatan tersebut tidak menyebar melampaui daerah-daerah yang ada di bawah pelaksanaan hakhak kedaulatan Negara terkait.

Tindakan-tindakan yang dilakukan untuk mencegah, mengurangi, dan mengendalikan pencemaran lingkungan laut harus mencakup tindakan-tindakan yang direncanakanuntukmengurangisebesar mungkin terjadinya pencemaran. Dan UNCLOS 1982 menyebutkan empat pencemar lingkungan laut, sebagai berikut: ${ }^{23}$

1. The release of toxic, harmful or noxious substances, especially those which are persistent, from land-based sources, from or through the atmosphere or by dumping.

2. Pollution from vessels, in particular measures for preventing accidents and dealing with emergencies, ensuring the safety of operations at sea, preventing intentional and unintentional discharges, and regulating the design,

23 Pasal 194 (3) UNCLOS 1982. 
construction, equipment, operation, and manning of vessels.

3. Pollution from installations and devices used in exploration or exploitation of the natural resources of the seabed and subsoil, in particular measures for preventing accidents and dealing with emergencies, ensuring the safety of operations at sea, and regulating the design, construction, equipment, operation and manning of such installatios or devices.

4. Pollution from otherinstallations and devices operating in the marine environment, in particular measures for preventing accidents and dealing with emergencies, ensuring the safety of operations at sea, and regulating the design, construction, equipment, operation and manning of such installations or devices.

Bab XII UNCLOS 1982, mewajibkan negara-negara peserta untuk melakukan upaya-upaya yang dipandang perlu guna mencegah, mengurangi dan mengawasi pencemaran lingkungan laut dari sumber-sumber manapun baik dari daratan (pembuangan sampah rumah tangga dan deterjen berlebih, penggunaan pestisida yang melebihi ambang batas yang diperbolehkan, pencemaran air sungai, dan lain-lain) ataupun laut. UNCLOS 1982 juga mengatur kewajiban negara peserta untuk memastikan bahwa tindakan eksplorasi dan eksploitasi kekayaan laut di dalam jurisdiksi nasionalnya tidak mengakibatkan kerusakan dan pencemaran lingkungan laut wilayahnya sendiri danjuga lingkungan laut negara lain.

Negara peserta UNCLOS 1982 diwajibkan untuk bekerjasama secara bilateral, regional dan global baik secara langsung ataupun melalui organisasi internasional dalam merumuskan aturan-aturan, standarstandar dan rekomendasi praktek serta prosedur guna melindungi dan memperhitungkan keadaan regional bersangkutan ${ }^{24}$. Apabila suatu negara mengetahui tentang ancaman atau pencemaran lingkungan yang sudah terjadi di wilayah lintas batas, negara tersebut harus memberitahukan negara lain yang mungkin tercemar dan organisasi internasional yang terkait atas peristiwa ancaman atau pencemaran lingkungan laut lintas batas tersebut ${ }^{25}$.

UNCLOS 1982 juga menetapkan hak negara-negara peserta untuk mengelola sumbersumber kekayaan alam mereka sesuai dengan kebijaksanaan lingkungan dari masing-masing negara ${ }^{26}$. UNCLOS 1982 juga mengatur hal-hal yang berkaitan dengan pertanggungjawaban terhadap kerusakan lingkungan laut, hak kekebalan bagi kapal perang

24 Pasal197 UNCLOS 1982

25 Pasal 198 UNCLOS 1982

26 Pasal 193 UNCLOS 1982 
dan kapal-kapal pemerintah serta kaitan dari Bagian XII UNCLOS 1982 tentang Perlindungan dan Pemeliharaan Lingkungan Laut dengan kewajiban-kewajiban yang tercantum pada konvensi-konvensi lainnya guna perlindungan lingkungan laut.

Di bidang lingkungan hidup pada umumnya, pada tahun 1972, diadakan suatu Deklarasi mengenai lingkungan yang diselenggarakan di Stockholm.Deklarasi tersebut menghasilkan beberapa prinsip dasar yang bertujuan untuk menjaga dan melestarikan lingkungan. Dan berikut beberapa prinsip yang berkaitan dengan penulisan ini, yaitu: ${ }^{27}$

1. Prinsip 7:

Negara sebaiknya mengambil semua langkah yang memungkinkan untuk mencegah pencemaran laut oleh zatzat yang bertanggung jawab membahayakan kesehatan manusia hidup dan kehidupan laut, fasilitas merusak atau yang bertentangan dengan pemanfaatan laut yang sah lainnya.

2. Prinsip 21:

Negara-negara telah sesuai dengan Piagam Perserikatan Bangsa-Bangsa dan prinsipprinsip hukum internasional, hak berdaulat untuk mengeksploitasi sumber daya mereka sendiri sesuai dengan kebijakan lingkungan mereka sendiri,

27 Declaration of The United Nations Conference on the Human Environment, Stockholm 1972 dan tanggung jawab untuk memastikan bahwa aktivitas dalam yurisdiksi atau kontrol mereka tidak menyebabkan kerusakan untuk lingkungan Negara-negara lainnya atau kawasan di luar batas yurisdiksi nasional.

3. Prinsip 22:

Negara-negara akan bekerja sama untuk mengembangkan lebih lanjut hukum internasional tentang tanggung jawab dan kompensasi untuk korban pencemaran dan kerusakan lingkungan lainnya yang disebabkan oleh kegiatan dalam yurisdiksi atau pengawasan Negara-negara tersebut untuk kawasan di luar yurisdiksi mereka.

4. Prinsip 24:

Masalah internasional mengenai perlindungan dan perbaikan lingkungan harus ditangani dalam semangat kerjasama oleh semua negara, besar dan kecil, pada pijakan yang sama. Kerjasama multilateral atau bilateral melalui pengaturan atau sarana lain yang tepat sangat penting untuk mengendalikan, mencegah, mengurangi dan menghilangkan secara efektif dampak merugikan lingkungan akibat kegiatan yang dilakukan di semua bidang, sedemikian rupa yang berdampak pada nilai yang diambil dari kedaulatan dan kepentingan semua Serikat. 
Dari banyaknya perjanjianperjanjian serta kesepakatan internasional utamanya di bidang lingkungan, Phillip Sands dalam bukunya merumuskan beberapa prinsip umum yang sering dijadikan dasar untuk menegakkan hukum lingkungan internasional, yaitu diantaranya $:^{28}$

1. The obligation reflected in principle 21 of the Stockholm Declaration and Principle 2 of the Rio Declaration, namely, that states have sovereignty over their natural resources and the responsibility not to cause transboundary environmental damage. Sovereignty over natural resources and the responsibility notto cause damage to the environment of other states or toareas beyond national jurisdiction. Bahwa setiap negara memiliki kedaulatan atas sumber daya alam di dalam wilayah negaranya dan bertanggung jawab penuh untuk tidak menimbulkan kerusakan lingkungan bagi negara lain atau yang masih berada di dalam yurisdiksi nasionalnya.

2. The Principle of Preventive Action.

3. The Principle of Co-operation.

4. The Principle of Sustainable Development.

5. The Precautionary Principle.

6. The Polluter Pays Principle.

28 Phillipe Sands, 2003, Principle of International Environmental Law. Cambridge University Press, United Kingdom, hlm. 231- 285.
7. The Principle of Common but Differentiated Responsibility.

Berkaitan dengan permasalahan dalam penelitian ini yang melibatkan Indonesia dan australia, terdapat beberapa bentuk kerjasama, baik bilateral, regional, maupun internasional dalam hal perlindungan dan pemeliharaan lingkungan laut lintas batas, yaitu:

1. Kerjasama Bilateral

MoU between the Government of Australia and Indonesia on Oil Pollution Preparedness and Response 1996, yang mengandung butir-butir kerjasama antara lain sebagai berikut:

1. Promosi kerjasama yang saling menguntungkan di dalam kesiapan di dalam merespon polusi minyak di laut;

2. Kerjasama pertukaran informasi atas insiden pencemaran minyak di laut;

3. Inspeksi lapangan pada lokasi insiden minyak di laut yang sedang terjadi untuk kerjasama yang saling menguntungkan antar kedua belah pihak;

4. Pelatihan dan pendidikan bersama untuk capacity building yang lebih baik;

5. Promosi untuk melakukan riset dan penelitian di dalam menciptakan 
ukuran (measures), teknik, standar dan peralatan yang diperlukan;

6. Kerjasama tanggap darurat seperti mobilisasi personil, logistik dan peralatan lain yang dibutuhkan di dalam situasi darurat, dan lainlain.

2. Kerjasama Regional

Dalam lingkup ASEAN, salah satu kerjasama mengenai pencemaran minyak yang relevan dengan permasalahan yang diteliti adalah $M o U$ for ASEAN Oil Spill Response Action Plan (ASEAN-OSRAP) 1992, yang mengandung butirbutir kerjasama berikut:

a. Meningkatkan kemampuan negara peserta untuk merespon insiden pencemaran minyak di laut yang terjadi di wilayah negara-negara ASEAN;

b. Membentuk skema kerjasama untuk pemberian bantuan yang saling menguntungkan diantara negara anggota ASEAN;

c. Membuat prosedur pengelolaan bencana di dalam merespon insiden pencemaran minyak di laut yang terjadi di wilayah negara-negara ASEAN; dan

d. Membuat skema bantuan eksternal dan internal yang diperlukan di dalam merespon insiden pencemaran minyak di laut yang terjadi di wilayah negara ASEAN, dan lainlain.

3. Kerjasama Global

Salah satu kerjasama global mengenai penanganan pencemaran minyak yang cukup relevan dengan permasalahan dalam penelitian ini adalah International Convention on Civil Liability for Oil Pollution Damage $\quad$ (CLC) dan the International Oil Pollution Compensation (IOPC) Funds 1992, yang mengandung butirbutir kerjasama antara lain:

a. CLC dimaksudkan untuk memastikan bahwa tersedia kompensasi yang cukup bagi pihak-pihak yang terkena dampak pencemaran laut akibat tumpahan minyak yang berasal dari kecelakaankecelakaan kapal.

b. Dalam CLC, kecuali terbukti bahwa kesalahan mutlak berada pada suatu pihak, terdapat batas pertanggung jawaban (limit of liability) atas jumlah kompensasi yang ditanggung oleh pihakpihak yang terlibat di dalam suatu insiden pencemaran laut. Oleh karena itu IOPC $F u n d s$ menyediakan dana tambahan apabila 
kerugian yang ditimbulkan melebihi limit

liability yang diatur di dalam CLC tersebut, dan lain-lain.

\subsection{Penyelesaian Internasional \\ Pencemaran Laut}

Sudah menjadi kewajiban PBB untuk mendorong agar sengketasengketa diselesaikan secara damai. Dua tujuan tersebut adalah reaksi yang timbul akibat pecahnya Perang Dunia II.PBB berupaya agar perang dunia baru tidak kembali terjadi dan PBB harus bekerja keras agar sengketa yang terjadi antar Negara dapat diselesaikan sesegera mungkin secara damai.

Tujuan PBB sebagaimana yang diamatkan dalam Pasal 1 Piagam PBB, adalah untuk menciptakan perdamaian dan keamanan internasional.

To maintain international peace and security, and to that end: to take effective collective measures for the prevention and removal of threats to the peace, and for the suppression of acts of aggresion or other breaches of the peace, and to bring about peaceful means, and in conformity tih the principles of justice and international law, adjustment or settlement or international disputes or situations which might lead to a breach of the peace.
Penyelesaian sengketa yang seharusnya ditempuh ketika terjadi sengketainternasional demiterciptanya kedamaian dan keamanan internasional adalah penyelesaian sengketa secara damai yang terdapat di dalam pasal 33 Piagam yang mencantumkan beberapa cara damai dalam menyelesaikan sengketa, diantaranya :

a. Negosiasi

b. Penyelidikan atau inquiry

c. Mediasi

d. Konsiliasi

e. Arbitrase

f. Judicial Settlement atau pengadilan

g. Organisasi Internasional

Dari tujuh metode penyelesaian sengketa yang tercantum dalam Piagam, kemudian dikelompokkan menjadi dua bagian, yaitu penyelesaian sengketa secara Diplomatik/politik dan penyelesaian sengketa secara Hukum. Yang termasuk penyelesaian sengketa secara diplomatik adalah, Negosiasi, Inquiry, Mediasi, Konsiliasi. Sedangkan yang termasuk dalam penyelesaian sengketa secara hukum adalah, Arbitrase dan penyelesaian sengketa melalui pengadilan. Selain itu, di dalam hukum internasional publik juga dikenal penyelsesaian sengketa menggunakan jasa baik atau good offices yang dapat pula digolongkan dalam penyelesaian sengketa secara diplomatik.

Menurut Starke, Cara-cara penyelesaian sengketa damai, yaitu apabila para pihak telah dapat 
menyepakati untuk menemukan suatu solusi yang bersahabat, antara lain meliputi :29

\section{a. Negosiasi}

Negosiasi merupakan metode penyelesaian sengketa yang paling tua. Proses penyelesaian sengketa dengan metode ini hanya melibatkan para pihak, para pihak bertemu untuk menyelesaikan sengketa yang timbul diantara mereka. Namun, setelah abad ke-20, cara-cara lain untuk menyelesaikan sengketa telah dibuat dengan tujuan untuk mempermudah perundingan, sehingga munculah metodemetode penyelesaian sengketa dalam bentuk-bentuk lain.

b. Jasa-jasa baik

Proseduriniberasaldarikebiasaan yang kemudian dikodifikasikan oleh Konvensi Den Haag 29 Juli 1899. Jasa-jasa baik (good offices) berarti intervensi negara ketiga yang merasa dirinya wajar untuk membantu penyelesaian sengketa yang terjadi antara dua negara. dalam hal ini negara ketiga menawarkan jasa-jasa baiknya.

Intervensi dalam bentuk jasa-jasa baik ini adalah bentuk campur tangan yang sangat sederhana dari negara ketiga karena negara tersebut membatasi dirinya dan hanya menggunakan pengaruh

29 J.G. Starke, 1988, Pengantar Hukum Internasional 2, Edisi Kesepuluh, Sinar Grafika, Jakarta, hlm. 646. moral atau politiknya agar negara-negara yang bersengketa mengadakan hubungan satu sama lain atau mengadakan hubungan kembali bila hubungan tersebut telah diputus.

Secara prinsip, negara yang menawarkan jasa-jasa baiknya tidak ikut secara langsung dalam perundingan-perundingan, tetapi hanya menyiapkan dan mengambil langkah-langkah yang perlu agar negara yang bersengketa dapat bertemu satu sama lain dan menyelesaikan sengketa diantara mereka.

Prinsip intikad baik dapat dikatakan sebagai prinsip fundamental dan paling sentral dalam penyelesaian sengketa antarnegara, prinsip ini mensyaratkan dan mewajibkan adanya itikad baik dari para pihak dalam menyelesaikan sengketanya. Prinsip goodfaith ini tercantum dalam Manila Declaration alinea 1 paragraf 1 , yang berbunyi:

All state shall act in good faith and in conformity with the purpose and pinciplesenshrired in the charter of the United Nations with a view to avoiding disputesamong themselves

Prinsip selain good faith tercantum dalam Manila Declaration juga terdapat dalam Bali Concord 1976 Pasal 13, yang menyatakan : 
The highcontractingparties shall have the determination and good faith to prevent disputes from arising.

Dalam penyelesaian sengketa prinsip good faith tercermin dalam 2 (dua) tahap, yang pertama prinsip itikad baik diisyaratkan untuk mencegah timbulnya sengeketa yangdapat mempengaruhi hubungan baik antarnegara, yang kedua, bahwa prinsip goodfaith ini diisyaratkan harus ada ketika para pihak menyelesaikan sengketanya melalui cara-cara penyelesaian sengketayang dikenal dalam hukum internasional.

c. Mediasi

Mediasi merupakan bentuk campur tangan pihak ketiga dalam menyelesaikan sengketa diantara para pihak, yang lebih nyata. Dalam mediasi, negara ketiga tidak hanya sekedar mengusahakan agar negaranegara yang bersengketa saling bertemu, tetapijugamengusulkan dasar-dasar perundingan dan ikut serta secara aktif dalam perundingan.

Antara jasa baik dan mediasi hampir serupa, namun pada prinsipnya sebuah jasa baik, pihak ketiga yang memberikan penawaran bantuan penyelesaian sengketa tidak lagi berasumsi untuk melakukan negosiasi. Sedangkan pada mediasi, intervensi para pihak mengambil bagian dalam proses tersebut. ${ }^{30}$

d. Konsiliasi

Konsiliasi adalah suatu cara penyelesaian secara damai sengketa internasional oleh suatu organ yang telah dibentuk sebelumnya atau dibentuk kemudian atas kesepakatan pihak-pihak yang bersengketa setelah lahirnya masalah yang dipersengketakan. Dalam hal ini organ tersebut mengajukan usulusul penyelesaian kepada pihakpihak yang bersengketa. Komisi konsiliasi bukan saja bertugas mempelajari fakta-fakta akan tetapi juga harus mempelajari sengketa dari semua segi agar dapat merumuskan suatu penyelesaian.

e. Penyelidikan (Fact Finding/ Enquiry)

Fact Finding dan Enquiry keduanya mempunyai definisi yang sama dalam hal ini yaitu penyelidikan/mencari fakta. Dalam konteks hubungan internasional dapat dimaknai sebagai suatu proses untuk menemukan suatu fakta atau kebenaran yang dilakukan oleh tim penyelidik yang netral. Maksud dari diadakannya penyelidikansuatukasussengketa adalah untuk menyelesaikan

30 EllieLouka,2006, InternationalEnvironmental Law : Fairness, Effectiveness and World Order, Cambridge University Press, New York, hlm. 56 
permasalahan atau konflik yang timbul karena adanya perbedaanperbedaan mengenai fakta. Penyelidikan hanya ditekankan pada fakta-fakta yang mendasari suatu sengketa, bukan untuk permasalahan yang bersifat hukum murni.Dasar hukum dari pencarian fakta/penyelidikan (fact finding atau Enquiry) ini adalah Hague Convention on The Pacific Settlement of Disputes 1907, Pasal 9-36.Pasal-pasal dalam konvensi ini mengatur cara-cara penyelesaian sengketa dengan membentuk komisi pencari fakta.

Suatu prosedur penyelesaian sengketa secara damai dikatakan berhasil adalah apabila para pihak yang terlibat sengketa secara bersamasama menyatakan menerima dan puas akan hasil rekomendasi atau keputusan prosedur penyelesaian sengketa yang dilakukan. ${ }^{31}$ Dan prosedur berikut merupakan prosedur penyelesaian sengketa secara hukum yang dapat dipilih para pihak, yaitu:

1. Penyelesaian Sengketa Melalui Arbitrase

a. Pengertian Arbitrase

Arbitrase adalah intitusi hukum alternative bagi penyelesaian sengketa diluar peradilan. Penyelesaian sengketa alternatif sudah lama dikembangkan,

31 Bernard Sipahutar, 2008, Penyelesaian Sengketa Internasional Dalam Kerangka UNCLOS, Majalah hukum Forum Akademika, Fakultas Hukum Universitas Jambi, hlm.35 baik dibarat maupun ditimur. Hal tersebut dikarenakan alasan-alasan praktis seperti lamanya waktu yang ditempuh bila penyelesaian sengketa dipengadilan, biaya yang besar sampai kepada alasan-alasan kebudayaansehinggamasyarakat lebih menyukai menyelesaikan sengketa diluar pengadilan. ${ }^{32}$

Kata arbitrase berasal dari bahasa latin yaitu Arbitrare. Arbitrase juga dikenal dengan debutan atau istilah lannya yang memiliki maksud yang sama seperti misalnya pewsitan, atau arbitrage (Belanda) arbitration (Inggris), arbitrage atau schiedspruch (jerman), Arbitrage (prancis), kesemunya memiliki arti yang sama yaitu kekuasaan untuk menyelesaikan sesuatu menurut kebijaksanaan. Dihubungkannya arbitrase menurut kebijaksanaan itu, dapat menimbulkan salah pengertian tentang arbitrase, karena dapat menimbulkan kesan seolah-olah seorang arbirter atau majelis arbirter dalam menyelesaikan suatu sengketa tidak mengindahkan norma-norma hukum lagi dan menyandarkan pemutusan sengketa tersebut hanya pada kebijaksanaan. Kesan tersebut keliru, karena arbirter atau majelis tersebut

32 M. Faisal Salam, 2007, Penyelesaian Sengketa Bisnis secara Nasional dan Internasional, mandar maju, Bandung, hlm. 140. 
juga menerapkan hukum seperti apa yang dilakukan oleh hakim atau pengadilan. ${ }^{33}$

Adapun definisi arbitrase menurut Gill adalah arbiration is the reference of a dispute or difference between not less than two persons for determination after hearing both sides in a judicial manner by another person or persons, other than a court of competent jurisdiction. ${ }^{34}$ Arbitrase adalah penyerahan sengketa atau perbedaan diantara tidak kurang dari dua orang untuk mendapatkan putusan setelah mendengar kedua belah pihak dalam cara yudisial (pemeriksaan / Pemutusan) oleh orang atau orang-orang lain, selain dari pengadilan yang mempunyai yurisdiksi hukum. Sedangkan Soebekti memberi pengertian bahwa arbitrase adalah suatu perselisihan (perkara) oleh seorang atau beberapa orang wasit (arbiter) yang bersamasama ditunjuk oleh para pihak yang berperkara dengan tidak diselesaikan lewat pengadilan. ${ }^{35}$ Definisi lainnya adalah

33 R. Soebekti, 1981, Arbitrse Dagang, Bina Cipta, Jakarta, hlm.1

34 Enid A. Marshall, 1988, Gill: The Law of Arbitration, Sweet \& Maxwell, London, hlm. 1.

35 Priyatna Abdurrasyid, 2002, Pengusaha Indonesia Perlu Meningkatkan Minatnya Terhadap Arbitrase dan Alternatif Penyelesian Sengketa (Alternative Dispute Resolution ADR/ Arbitration), suatu Tinjauan, Jurnal Hukum Bisnis (edisi Oktober - November 2002), hlm. 7 dikemukakan oleh Abdul kadir, ken Hoyle, Geoffrey, Whitehead. Mereka memberikan batasan lembaga ini yaitu: menyerahkan sukarela suatu sengketa kepada seseorang yang berkualitas untuk menyelesaikan dengan suatu perjanjian bahwa keputusan arbitrator akan final dan mengikat para pihak yang berperkara. ${ }^{36}$ Sedangkan definisi dalam peraturan perundang-Undangan adalah bahwa Arbitrase adalah cara penyelesaian suatu sengketa perdatadi luar peradilan umum yang didasarkan pada perjanjian arbitrase yang dibuat secara tertulis oleh para pihak yang bersengketa. ${ }^{37}$

Berdasarkan pengertianpengertian diatas, pada dasarnya dapat disimpulkan bahwa unsur-unsur arbitrase adalah sebagai berikut: 1). Cara penyelesaian sengketa secara privat atau diluar pengadilan; 2).Atas dasar perjanjian tertulis dari para pihak; 3).Untuk mengantisipasi sengketa yang mungkin terjadi atau yang sudah terjadi; 4).Melibatkan pihak ketiga (arbiter atau wasit) yang berwenang mengambil keputusan; dan

36 Huala Adolf, Hukum Arbitrase Komersil Internasional, Raja Grafindo Persada, Yakarta, hlm 11.

37 UU No 30 tahun 1999 tentang Arbitrase Dan Alternatif Penyelesaian Sengketa, Pasal 1 ayat (1) . 
5).Sifat putusannya final dan mengikat. ${ }^{38}$

b. Kelebihan, Kekurangan

Arbitrase.

Arbitrase

merupakan

pemeriksaan atau penyelesaian sengkata secara privat. Para pihak, baik yang mengantisipasi sengketa yang mungkin terjadi maupun yangs edang mengalami sengketa yang tidak mampu diselesaikan melalui musyawarah, sepakat untuk menyerahkan sengketanya kepada pengambil keputusan privat dengan cara-cara yang mereka tentukan bersama. Dengan cara ini para pihak menghindari penyelesaian sengketa melalui badan peradilan umum. ${ }^{39}$

Terdapat berbagai macam alasan para pihak memilih penyelesaian melalui arbitrase. Alasan tersebut adalah:

c. Kebebasan, kepercayaan, dan keamanan: memberikan kebebasan kepada para pihak serta kenyamanan terhadap keadaan yang tidak menentu.

d. Keahlian: para pihak bebas memilih orang yang ahli dibidang yang mereka sengketakan.

e. Cepat dan hemat biaya: tidak perlu menunngu lama untuk mendapatkan hasil, biaya ringan.

38 Bambang Sutiyoso, Hukum Arbitrase dan Alternatif Penyelesaian sengketa, Gama Media, Yogyakarta, 2008. hlm. 111.

39 Rachmat usman, 2002, Hukum Arbitrase nasional, Grasindo, Jakarta, hlm. 18-19 f. Bersifat rahasia: dalam lingkungan yang bersifat rahasia dan privat

g. Bersifat nonpresedent: tidak memiliki sifat presedent.

h. Kepekaan arbiter: lebih mementingkan kepentingan privat dibandingkan kepentingan umum.

i. Pelaksanaan putusan: lebih mudah dilaksanakan dibandingkand engan keputusan pengadilan.

j. Kecenderungan yang moderen.

Hukum internasional telah mengenal arbitrase sebagai alternatif penyelesaian sengketa, dan cara ini dianggap sebagai cara yang efektif dan adil dalam penyelesaian sengketa. Karena arbitrase berbeda dengan peradilan biasa dimana para pihak dapat memilih aturannya, menunjuk arbiter, menentukan prosedur yang akan digunakan dan mengindikasikan aturan hukum yang sesuai sampai dengan batas waktu tertentu. ${ }^{40}$ Para pihak yang ingin bersengketa dengan menggunakan metode arbitrase dapat menggunakan badan arbitrase yang telah terlembaga. Pada saat ini terdapat sebuah lembaga arbitrase internasional yang terlembaga, yaitu Permanent Court of Arbitration (PCA). Dalam menjalankan tugasnya sebagai jalur penyelesaian sengketa, PCA menggunakan UNCITRAL Arbitration Rules 1976.

$40 \quad$ Ellie Louka, Op.cit, hlm. 57. 


\section{Penyelesaian Yudisial}

Organ umum yang tersedia untuk masyarakat internasional dalam penyelesaian sengketa secara yudisial adalah International Court of Justice (ICJ) di Den Haag. Organ umum ini dibentuk berdasarkan bab IV (pasal 92 - 96) Piagam PBB yang dirumuskan di San Fransisco pada tahun 1945.

ICJ/Mahkamah Internasional terdiri dari 15 hakim.Hakim-hakim ini merupakan sebuah panel para calon anggota mahkamah yang dinominasikan oleh kelompok National Panel Permanent Court of Arbitration.Daftar dari calon ini, Majelis Umum dan Dewan Keamanan, yang secara independen melakukan pemungutan suara, memilih anggotaanggota mahkamah.Untuk pemilihan tersebut disyaratkan suara terbanyak mutlak baik dalam Majelis Umum maupun Dewan Keamanan.Prosedur untuk pemilihan yang bersamaan waktunya oleh majelis umum dan Dewan Keamanan berlaku juga pada kasus pengisian lowongan-lowongan tidak tetap, misalkan pemilihan yang dikarenakan meninggalnya atau pensiunnya seorang hakim.

Mahkamah Internasional secara umum memiliki 2 macam kewenangan:

1. Kewenangan untuk memutus perkara-perkara pertikaian (Contentious Case), yang pada prinsipnya, dalam kasuskasus pertikaian pelaksanaan yurisdiksi, mensyaratkanadanyapersetujuan para pihak. Menurut pasal 36 ayat 1 Statuta, Mahkamah memiliki yurisdiksi terhadap semua perkara yang diajukan para pihak yang bertikai. Pengajuan tersebut biasanya dilakukan dengan memberitahukan suatu perjanjian bilateral yang dinamakan Compromis.

2. Kewenangan untuk memberikan saran (Advisory Opinion). Advisory Opinion adalah hak Majelis Umum dan Dewan Keamanan PBB atas Mahkamah Internasional.

a. The General Assembly or the Security Council may request the International Court of Justice to give an advisory opinion on any legal question.

b. Other organs of the United Nations and specialized agencies, which may at any time be so authorized by the General Assembly, may also request advisory opinions of the Court on legal questions arising within the scope of their activities. ${ }^{41}$

Selain dua pihak ini, organorgan lain dari PBB, dengan izin Majelis Umum, juga berhak meminta mahkamah untuk memberikan opini-opini berupa nasihat tentang persoalan hukum yang timbul dalam lingkup aktivitas mereka. Dan opini-

41 Pasal 96, Piagam PBB 
opini tersebut dapat diupayakan atas persoalan hukum, baik konkret maupun abstrak.

Sebagai organ umum dalam hal penyelesaian sengketa, Mahkamah Internasional memiliki lembagalembaga peradilan yang lebih mengkhusus, utamanya berkaitan dengan kasus pencemaran laut.Ketika timbul permasalahan mengenai sengketa laut, International Tribunal for The Law of the Sea (ITLOS) merupakan lembaga peradilan yang berwenang menyelesaikannya.

Metode penyelesaian sengketa laut yang telah ada sejauh ini dianggap dapat digunakan padasemua jenis perselisihan dan tersedia untuk semua negara. Metode umum bersama ini dapat ditemukan prosedur khusus yang dibuat oleh kelompok-kelompok tertentu dari negara untuk penyelesaian sengketa didaerah tertentu. ${ }^{42}$

Dalam hal tidak tercapainya suatu kesepakatan dalam penyelesaian sengketa secara damai, maka para pihak dapat menggunakan prosedur wajib yang menghasilkan keputusan yang mengikat. Bab XV khususnya Pasal287UNCLOS 1982 menyediakan empat forum yang dapat dipilih untuk penyelesaian sengketa yaitu: ${ }^{43}$

1. Mahkamah Internasional Hukum Laut (International Tribunal for The Law of The Sea-ITLOS).

2. Mahkamah Internasional (International Court of Justice)

\footnotetext{
42 J. G. Merrills, 2005, "International Dispute Settlement", $4^{\text {th }}$ Edition, Cambridge University Press, hlm. 198

43 Bernard Sipahutar, Loc. Cit.
}

3. Mahkamah Arbitrase (Arbitral Tribunal)

4. Mahkamah Arbitrase Khusus (Special Arbitral Tribunal)

Penyelesaian sengketa mengenai pencemaran lingkungan laut di dalam UNCLOS 1982 di bahas pada Bab XV, yang berisikan kewajiban serta prosedur penyelesaian sengketa.Penyelesaian sengketa internasional dalam hal penyelesaian lingkungan laut berkaitan erat dengan pertanggungjawaban negara. Sejauh ini, ternyata belum ada instrumen hukum internasional yang mengatur pertanggungjawaban negara pada umumnya yang diterapkan terhadap persoalankerusakanlingkungan. Untuk itu, International Law Commission (ILC) telah mencoba membuat rancanganketentuan-ketentuan tentang pertanggungjawaban Negara, yaitu sebagaimana tertuang dalam ILC draft articles on state responsibility. ${ }^{44}$ Sesuai dengan asas sic utere tuo ut alienum non laedas ${ }^{45}$ atau the principle of good neighbourlines, atas sengketa ini, diupayakan penyelesaian sengketa melalui jalur diplomatik.

44 1999."PertanggungjawabanNegara Terhadap Pencemaran Lingkungan Internasional", Mimbar Hukum Universitas Gadjah Mada No.33/X/1999, hlm. 176.

45 Sic utero tuo ut alienum non laedas :suatu prinsip hukum yang mengatur tentang kewajiban pengguna hak milik yang tidak merugikan pihak lain. Lihat: Siahaan N.H.T., 2004. Hukum lingkungan dan Ekologi Pembangunan, Erlangga, Jakarta, hlm. 355 


\subsection{Contoh Kasus Penyelesaian Sengketa \\ Internasional}

Dalam lingkup internasional, terdapat beberapa kasus mengenai pencemaran, antara lain:

\section{Arbitrase Trail Smelter ${ }^{46}$}

Pada tahun 1906, Consolidated Mining and Smelting Company of Canada, Limited, sebuah perusahaan tambang mendirikan Smelter Plant di Kanada dan perusahaan tersebut memiliki di Trail ketika perusahaan tersebut didirikan. Sejak saat itu, perusahaan Kanada, tanpa gangguan, telah mengoperasikan Smelter dari waktu ke waktu sampai Smelter tersebut menjadi SmeltingPlant terbesar di benua itu.

Pada tahun 1925 dan 1927, dua tumpukan bijih setinggi 409 kaki diproses. Penambahan produk ini menghasilkan asap sulfur dioksida dibuang ke udara, dan mencapai Amerika Serikat. Pada tahun 1916, sekitar 5000 ton sulfur per bulan dikeluarkan; pada tahun 1924, sekitar 4700 ton dan pada tahun 1926, sekitar 10000 ton, atau dengan kata lain, sebanyak 300-350 ton sulfur dikeluarkan setiap harinya pada tahun 1930. Sejak tahun 1925 dan setidaktidaknya, sampai akhir tahun 1931 kerusakan terjadi di negara bagian

46 Smelter adalah sebuah alat yang digunakan untuk memisahkan bijih besi dari bebatuan dengan cara memurnikannya (permurnian dengan cara memanaskan pada suhu yang sangat tinggi); atau pabrik yang menggunakan alat tersebut. Lihat: Cambridge Dictionary, www.cambridge.dictionary.org, Diakses pada tanggal 09 Agustus 2012.
Washington sebagai akibat dari sulfur dioksida yang dikeluarkan oleh Trail Smelter. ${ }^{47}$

Dua tahun kemudian, pemerintah Amerika Serikat menyampaikan keluhan kepada pemerintah Kanada yang intinya mengemukakan bahwa kondisi-kondisi yang ada masih jauh dari memuaskan dan kerusakan terus berlangsung, sehingga perlu diadakan pembaharuan pembicaraan diplomatik. Kedua negara sepakat untuk membawa persoalan ini ke badan arbitrase, berdasarkan konvensi yang berlaku di kedua negara yang ditandatangani tanggal 15 April 1935.

Mulai tahun 1920, produksi emisi perusahaan tersebut terus meningkat. Emisi tersebut mengandung sulfur dioksida, menyebarkan bau logam dan seng yang sangat menyengat. Pada tahun 1930 jumlah emisi tersebut mencapai lebih dari 300 ton sulfur setiap hari. Emisi tersebut, karena terbawa angin, bergerak ke arah wilayah AS melalui lembah sungai Columbia dan menimbulkan berbagai akibat merugikan terhadap tanah, air dan udara, kesehatan serta berbagai kepentingan penduduk Washington lainnya.

AS kemudian melakukan klaim terhadap Kanada dan meminta Kanada bertanggungjawab terhadap kerugian yang diderita AS.Setelah melakukan negosiasi, kedua negara sepakat untuk

\footnotetext{
47 Setiawan Y Sabungan, 2009 Pertanggungjawaban Negara dalam Perspektif Hukum Internasional, Fakultas Hukum Universitas Indonesia, hlm. 23.
} 
menyelesaikan kasus itu melalui International Joint Commision, suatu badan adminsitratif yang dibentuk berdasarkan Boundary Waters Treaty 1907.Badan tersebut tidak mempunyai yurisdiksi terhadap masalah-masalah pencemaran udara dan sesungguhnya hanya mempunyai yurisdiksi terhadap sengketa-sengketa yang berkaitan dengan masalah perbatasan perairan.

Sengketa terjadi akibat tercemarnya wilayah teritorial AS atas aktivitas industri smelter di Kanada. Kerusakan berasal dari sulphur dioxide $^{48}$ yang merupakan limbah dari smelter tersebut.AS membawa permasalahan tersebut ke ICJ untuk diinvestigasi yang kemudian hasilnya di presentasikan pada tahun 1931.Dan memberikan penjelasan bahwa sampai dengan 1 Januari 1932, kerusakan yang ditimbulkan oleh pemerintah AS dimintakan kompensasi sampai dengan US \$ 350,000. ${ }^{49}$ Dua tahun setelah report ini, AS mengindikasikan kepada Kanada bahwa kerusakan masih terjadi dan pada akhirnya terjadi pembaharuan negosiasi yang berujung pada penandatanganan sebuah konvensi.

48 Sulphur dioxide/Sulfur dioksida adalah senyawa kimia dengan rumus $\mathrm{SO} 2$. Ini adalah gas beracun dengan bau, tajam menjengkelkan, yang dikeluarkan oleh gunung berapi dan dalam berbagai proses industri. Lihat :http:// en.wikipedia.org/wiki/Sulfur_dioxide,Diakses pada tanggal 18 Agustus 2012.

49 Charles Okidi, 1998, Compendium of Judicial Decisions on Matters Related to Environment, UNEP/Dutch Joint Project on Environmental Law and Institutions in Africa, Nairobi, hlm. $\mathrm{X}$
Setelah mempertimbangkan keadaan yang berhubungan dengan kasus ini, Badan Arbitrase memutuskan bahwa negara Kanada bertanggung jawab menurut hukum internasional terhadap tindakannya di pabrik peleburan Trail. Pada 16 April 1938, mahkamah memutuskan bahwa telah timbul kerusakan di wilayah teritorial AS yang disebabkan oleh smelter di Trail. Kerusakan tersebut terjadi sejak 1 januari 1932 sampai dengan 1 oktober 1937, dan atas itu harus dibayarkan kerugian sebesar US $\$ 78,000^{50}$ sebagai ganti rugi final dan kompensasi atas semua kerusakan yang timbul dalam jangka waktu tersebut. Mahkamah menunda keputusan final, dan jika terdapat tambahan biaya kerusakan yang harus dibayarkan maka akan ditetapkan rezim yang lebih layak.

Pada 11 Maret $1941^{51}$, mahkamah memberikan keputusan final. Mahkamah harus menentukan apakah TrailSmelter memilikikewajibanuntuk menghentikan penyebab kerusakan di AS di masa yang akan datang. Ini menunjukkan bahwa belum ada kasus pencemaran baik udara maupun air yang telah ditangani oleh Mahkamah Internasional pada masa itu yang terkait dengan kasus ini (pencegahan jangka panjang).Dalam hal ini keputusan dari pengadilan tinggi AS dapat dijadikan acuan dalam hukum internasional sejauh mereka memiliki kontroversi

50 United Nations, 2006, Reports of International Arbitral Awards, Trail Smelter Case (United States and Canada), 16 April 1938 and 11 March 1941, Volume III pp.1905-1982. 51 Ibid 
dengan penanganan kasus antara negara-negara federal AS. Mahkamah dalam pengambilan keputusan tetap mempertimbangkan unsur-unsur yang mengandung prinsip-prinsip hukum internasional, yang juga merupakan prinsip yang dijunjung oleh hukum AS yaitu: "no state has right to use or permit the use of its territory in such a manner as to cause injury by fumes in or to the territory of another or the properties of the person therein". 52

\section{Arbitrase Lake Lanoux}

Lake (danau)Lanoux terletak di wilayah Perancis di sisi pegunugan Pyrenees $^{53}$.Danau ini mengalir ke beberapa anak sungai yang mengalir ke (hanya) wilayah Perancis.Namun pada kenyataannya airnya juga mengalir ke hulu sungai Carol, yang letaknya kirakira $25 \mathrm{~km}$ dari Danau Lanoux.

Pada 26 Mei 1866, Perancis dan Spanyol menandatangi persetujuan mengenai hak-hak dan kewajiban kedua negara dalam hal memanfaatkan potensi dari air yang bersumber di Danau Lanoux. Kesepakatan ini dilakukan di Bayonne-Perancis dan dikenal dengan sebutan Treaty of Bayonne. ${ }^{54}$

Kasus Danau Lanoux bermula dari rencana Perancis memanfaatkan potensi Danau Lanoux untuk keperluan pendirian hydroelectric.Sengketa

52 William R. Slomanson, 2011, Fundamental Perspectives on International Law, Wardsworth Cengage Learning, United States, hlm. 659.

53 Etang du Lanoux, http://en.wikipedia.org/wiki/ \%89tang_du_Lanoux, Diakses pada tanggal 16 Agustus 2012.

54 Treaty of Bayonne, 1866, Perancis. dimulai dari didirikannya perusahaan pembangkit listrik tenaga air Perancis yang menggunakan air dari danau tersebut.Penggunaan air tersebut menyebabkan berkurangnya jumlah debit air yg seharusnya juga mengalir ke Sungai Carol.

Spanyol berkeberatan terhadap rencana itu, karena khawatir sungaisungai Spanyol yang besumber pada danau itu mengalami pencemaran akibat limbah kimia dan perubahan suhu yang dihasilkan oleh teknologi yang digunakan, yang membahayakan kekayaan hayati sungai tersebut. Atas pertimbangan tersebut Spanyol mengajukan keberatan terhadap rencana Perancis.Dengan demikian terjadilah sengketa kepentingan antara kedua negara bersangkutan.Arbitrase yang dibentuk untuk menyelesaikan sengketa itu menggunakan asas good faith untuk menyelesaikan kasus tersebut.

Perjanjian Bayonne memberikan titik terang dari konflik yang terjadi. Pengadilan menemukan bahwa konflik terjadi atas kepentingan industrial kedua negara yang dapat didamaikan melalui konsesi timbal balik antara Perancis dan Spanyol. ${ }^{55}$ Dalam kasus ini, pengadilan berpendapat berdasarkan Pasal 11 Perjanjian:

When in one of the two States it is proposed to construct works or to grant new concessions which might change the course or the volume of 55 J. G. Lammers, 2001, International Organzations and The Law of The Sea Documentary Yearbook, Martinus Nijhoff Publishers, Netherlands, hlm. 635. 
a watercourse of which the lower or opposite part is being used by the riparian owners of the other country, prior notice will be given to the highest administrative authority of the Department or of the Province to which such riparian owners are subject by the corresponding authority in the jurisdiction where such schemes are proposed, so that, if they might threaten the rights of the riparian owners of the adjoining Sovereignty, a claim may be lodged in due time with the competent authorities, and thus the interests that may be involved on both sides will be safeguarded. If the work and concessions are to take place in a Commune contiguous to the border, the engineers of the other Country will have the option, upon proper notice given to them reasonably in advance, of agreeing to inspect the site with those in charge of it.

Bahwa Perancis tidak melakukan pelanggaran atas perjanjian ataupun terhadap aturan tambahan perjanjian.Perancis telah melakukan pemberitahuan kepada pihak Spanyol mengenai rencana pendirian pembangkit listrik tersebut.

Bahwa Negara hulu mempunyai kewajiban untuk mempertimbangan seluruh kepentingan yang terkait dengan setiap kegiatan yang ia lakukan didalam wilayahnya. Pertimbangan itu dimaksudkan untuk untuk menjamin tercapainya tujuan-tujuan kegiatan tersebut secara baik.Dalam perspektif prinsip good faith, setiap negara hendaknya hanya melakukan kegiatankegiatan yang bermanfaat dan juga baik bagi dirinya. Apa yang bermanfaat dan baik bagi dirinya, hendaknya juga dirasakan sama oleh negara lain, dan apa yang dirasakan merugikan oleh negara lain hendaknya juga dirasakan merugikan oleh negara pelaku kegiatan. Dengan demikian suatu negara hendaknya tidak mengerjakan kegiatan yang hanya menguntungkan dirinya dan merugikan negara lain, atau setiap negara hendaknya mengerjakan kegiatan-kegiatan yang tidak merugikan semua pihak. Prinsip diatas mengandung 2 (dua) makna, yang pertama, negara hulu wajib mepertimbangkan kepentingan negara hilir, yang kedua, negara hulu dalam menetapkan rencanarencananya, atau bertindak didalam wilayahnya tidaklah perlu menunggu persetujuan-persetujuan negara hilir, namun demikian adalah wajib bagi negara hulu untuk mempertimbangkan kepentingan negara hilir, agar tindakan yang dilakukan tidak menimbulkan kerugian terhadap negara hilir.

Pengadilan memandang bahwa proyek Perancis memenuhi kewajiban Pasal 11 UU Tambahan, dan bahwa Prancis dalam melaksanakan, tanpa kesepakatan awal antara kedua negara, bekerja untuk penggunaan air Danau Lanoux tidak melakukan suatu pelanggaran ketentuan Perjanjian Bayonne dari 26 Mei 1866 atau UU Tambahan. 
Pengadilan membahas hukum yang berlaku karena Pihak (Perancis dan Spanyol) tidak setuju pada isu internasional hak dankewajibanNegara berbagi sumber daya alam yang umum seperti air.Konsultasi dan negosiasi dengan itikad baik diperlukan tidak hanya sebagai formalitas belaka, tetapi sebagai upaya untuk menyimpulkan kesepakatan untuk pencegahan konflik. ${ }^{56}$

\section{British Petroleum Oil Spill}

Kebocoran sumur minyak lepas pantai yang pecah akibat ledakan di salah satu anjungan di Teluk Meksiko. Dalam peristiwa itu, 11 orang pekerja kilang lepas pantai BP tewas. Kebocoran ini diperkirakan mencapai 60.000 barel minyak setiap hari. Wilayah perairan di sepanjang pantai bagian selatan Amerika Serikat ini akan terus tercemar selama bertahun-tahun sebagai bencana ekologis terbesar. Banyak warga negara Amerika Serikat kehilangan penghasilannya yang bermata pencaharian di bidang perikanan dan pariwisata. Peristiwa ini terjadi pada April 2010, dengan pihak yang bertanggung jawab adalah British Petroleum Company (BP), perusahaan raksasa minyak Inggris.Kasus tersebut selesai dengan pemberian ganti rugi oleh BP 3,95 miliar dollar AS (semuanya dibiayai British Petroleum sendiri tanpa membebani APBN Amerika serikat) dan diselesaikan dalam kurun waktu yang cukup singkat, 15 Juli 2010.Dengan cara pemasangan

56 Charles Okidi, Op. cit. hlm. xi tutup-tutup baru yang lebih besar yang dipasang kru BP di atas tempat kebocoran. Presiden Amerika Serikat, Barack Obama, bahkan mengerahkan seluruh tenaga yang ada seperti kapalkapal angkatan laut (US NAVY) untuk bekerjasama dengan tim insinyur British Petroleum.

Untuk Indonesia sendiri, Kasus Minyak Montara bukanlah yang pertama, beberapa kasus pencemaran minyak di wilayah laut Indonesia, antara lain : $:^{57}$

a. Tanker Showa Maru, karam di Selat Malaka tahun 1975, menumpahkan 1 juta ton minyak mentah.

b. Choya Maru, karam di Buleleng, Bali (1975), menumpahkan 300 ton bensin.

c. Golden Win, bocor di Lhokseumawe, NAD (1979), menumpahkan 1.500 kiloliter minyak tanah.

d. Nagasaki Spirit, karam di Selat Malaka (1992), menumpahkan minyak mentah.

e. Maersk Navigator, karam di Selat Malaka (1993), menumpahkan minyak mentah.

f. Bandar Ayu, karam di Pelabuhan Cilacap (1994), menumpahkan minyak mentah.

g. Mission Viking, karam di Selat Makassar (1997), menumpahkan minyak mentah.

57 Tumpahan Minyak Perbatasan Harus Segera Diatasi, http://kiara.or.id/content/ view/1026/133/lang.id/, Diakses pada tanggal 12 Oktober 2011. 
h. MT Natuna Sea, karam di Pulau Sambu (2000), menumpahkan 4.000 ton minyak mentah.

i. MT Kharisma Selatan, terbalik di Dermaga Mirah, Pelabuhan Tanjung Perak, Surabaya (2007), menumpahkan 500 kiloliter MFO (marine fuel oil)

Penyebab kasus pencemaran laut tersebut secara umum adalah transportasi minyak, pengeboran minyak lepas pantai, pengilangan minyak dan pemakaian bahan bakar produk minyak bumi. Bahkan kasus pencemaran lingkungan laut oleh minyak yang baru saja terjadi adalahKecelakaan kapal tanker MV Bunga Kelana III yaitu kapal yang berbendera Malaysia dengan kapal berbendera Singapura. Akibatnya sebagian muatan minyak atau sekitar 2.500 ton yang berada dalam tangki kapal tanker MT Bunga Kelana III tersebut tumpah ke laut. Akibat insiden ini hampir seluruh perairan Selat Singapura yaitu kurang lebih seluas 2 kilometer persegi di sekitar tempat kejadian tertutup oleh tumpahan minyak.

Berdasarkan gambaran kasuskasus pencemaran lingkungan laut baik di dunia Internasional maupun ASEAN, penting bagi Indonesia untuk dapat melakukan tindakan-tindakan di bidang hukum untuk dapat melindungi kepentingan-kepentingan bangsa Indonesia atas laut dan lingkungan laut.

\subsection{Penyelesaian Sengketa Kasus Montara}

Berkaitan dengan penyelesaian Kasus Minyak Montara di Laut Timor, Pemerintah Indonesia dan Pemerintah Australia telah menempuh caracara damai, dengan mengutamakan negosiasi diantara para pihak. Pada dasarnya, Pemerintah Indonesia dan Australia telah menyadari bahwa kedua negara memiliki kepentingan dan keterkaitan dalam bidang pengelolaan lingkungan laut. Oleh karena itu, Pemerintah Indonesia dan Australia sejak tahun 1996 telah memiliki kerangka hukum dalam menyelesaikan berbagai kasus di bidang lingkungan laut yaitu sebuah Memorandum of Understanding (MoU) between the Government of Australia and Indonesia on Oil Pollution Preparedness and Response 1996.

Seperti kita ketahui bersama bahwa kasus pencemaran minyak merupakan suatu keadaan darurat. Hal ini disebabkan karena penyebab terjadinya yang tidak dapat diduga dan berlangsung sangat cepat sedangkan dampak yang diakibatkannya berlangsung secara cepat dan acak. Sehingga tidak dapat dilakukan pencegahan pertama selain respon terhadap dampak yang telah diakibatkan. Untuk itu, penting untuk dapat mengimplementasikan MoU 1996 tersebut.

Salah satu bentuk pertanggungjawaban serta itikad baik Australia menyikapi pencemaran yang 
terjadi ialah dengan mengupayakan pertanggungjawaban perusahaan penyebab terjadinya pencemaran yaitu PTTEP Australasia. Dan upaya tersebut menghasilkan beberapa langkah-langkah yang telah dilakukan oleh PTTEP Australasia dari sejak terjadinya peristiwa tumpahan sampai dengan pasca tumpahan. Mulai dari tindakan yang dikatagorikan sebagai tanggap darurat atas pencemaran sampai dengan pemantauan yang berkesinambungan berikutnya.

Akibat tumpahan minyak di laut Timor pada tahun $2009^{58}$, PTTEP Australasia menerima tanggung jawab untuk membiayai program pemantauan dampak pencemaran jangka panjang di bawah persetujuan bersama dengan Department for Sustainability, Environment, Water, Population and Communities (DSEWPaC).

Danbeberapakelompok/lembaga riset independen kelas dunia ambil bagian dalam program pemantauan tersebut, diantaranya kelompok riset :

- Beberapa Universitas terkemuka di Australia (Quensland, Curtin, Monash, dan Charles Darwin)

- $\quad$ Asia Pacific ASA

- CSIRD

- Australian Institute of Marine Science

Program pemantauan ini bertujuan untuk menemukan serta mengukur tingkat pencemaran yang terjadi di laut timor. Dan beberapa

58 PTTEP Australasia, 2012, The Montara Incident, http://www.au.pttep.com/ourresponse-to-montara/the-incident, Diakses pada tanggal 10 Agustus 2012. hasil dari riset tersebut, yaitu telah tercemarnya atau terganggunya kehidupan laut dan ekosistem laut oleh hidrokarbon di beberapa area. Namun sangat kecil atau hampir tidak ada dampaknya bagi kesehatan maupun beberapa spesies dan habitat laut. Tinjauan ilmiah dari riset menunjukkan tidak adanya minyak dari Montara yang mencapai perairan Australia maupun Indonesia.

PemerintahAustraliamembentuk suatu komisi penyelidik yang diberi nama Borthwick Commision Inquiry ${ }^{59}$ guna menyelidiki serta menjabarkan hal-hal yang berkaitan dengan penyebab terjadinya insiden Montara, serta upaya pencegahan terjadinya bencana serupa.

Dalam proses penyelidikan, seluruh karyawan PTTEP Australasia dan para kontraktor dari "Seadrill and Halliburton", yang berada di West Atlas rig pada saat terjadinya insiden, diwawancarai. Dan dari penyelidikan tersebut komisi memberikan laporan yang telah di publikasikan pada tanggal 24 November 2010, yang berisi 100 penemuan-penemuan dan 105 rekomendasi dimana sebagian besar diadopsi oleh pemerintah federal. ${ }^{60}$ Ditemukan beberapa akar permasalahan tumpahan minyak Montara:

59 Montara Commission of Inquiry, www. montarainquiry.gov.au, Diakses pada tanggal 14 Agustus 2012.

60 PTTEP Australasia, Commission of Inquiry, http://www.au.pttep.com/our-response-tomontara/commision-ofinquiry,Diakses pada tanggal 10 Agustus 2012 
- $\quad$ Kegagalan dalam pengawasan 2 anjungan montara

- Kegagalan dalam verifikasi anjungan

- Kurangnya manajemen kontrol

- Kurangnya kompetensi dari personil yang menyebabkan kurang tanggapnya pengambilan keputusan

Berdasarkan hal tersebut diatas, kementerian terkait mengumumkan pada bulan Februari 2011, bahwa ijin operasi PTTEP Australasia tidak dicabut namun perusahaan hanya diijinkan untuk di bawah rezim pemantauan yang paling komprehensif dan ketat yang pernah ada di industri minyak dan gas bumi Australia. ${ }^{61}$

PTTEP memulai dengan mengembangkan Montara Action Plan (MAP) segera setelah terjadinya insiden pada November $2009^{62}$. MAP berfokus pada tindakan jangka pendek, jangka menengah dan jangka panjang dari insiden, serta untuk memetik pelajaran dari insiden dengan 4 area kunci koordinasi :

- Pemerintah

- Organisasi terkait serta kapabilitasnya

- $\quad$ Sistem yang bersifat teknis

- Keselamatan, keamanan, kesehatan, dan budaya lingkungan serta pengelolaannya.

Pada bulan Oktober 2009,

61 Ibid

62 PTTEP Australasia, Montara Action Plan, http://www.au.pttep.com/our-response-tomontara/montara-action-plan,Diakses pada tanggal 10 Agustus 2012. tercapai kesepakatan antara PTTEP dengan Pemerintah Australia untuk mengembangkan program pemantauan lingkungan pada beberapa aspek jangka panjang akibat tumpahan. ${ }^{63}$ Program monitor ini dilakukan bersama oleh perusahaan dan DSEWPaC. Seluruh hasil penemuan ilmiah tersebut diolah kembali dan oleh lembaga independen dari DSEWPaC sebelum disahkan sebagai laporan resmi. Semua hasil riset bersifat transparan dan dipublikasikan secara resmi melalui website DSEWPaC. Dalam hal ini PTTEP setuju kepada Pemerintah Australiauntukmembiayaikeseluruhan penelitian, setidaknya dalam waktu kurang lebih 2 tahun. Dan tidak tertutup kemungkinan untuk penelitian tahap lanjutan sampai dengan 10 tahun ke depan.

Dalam kasus Minyak Montara metode yang digunakan dalam penyelesaiannya adalah negosiasi dengan tidak menutup kemungkinan penggunaan cara-cara lain sesuai dengan kesepakatan para pihak. Negosiasi adalah cara penyelesaian sengketa yang paling dasar dan yang paling tua digunakan oleh umat manusia.Penyelesaian melalui negosiasi merupakan cara yang paling penting.Banyak sengketa diselesaikan setiap hari melalui cara ini tanpa adanya publisitas atau perhatian publik. Salah satu sisi positifnya adalah

63 PTTEPAustralasia,EnvironmentalMonitoring, http://www.au.pttep.com/our-response-tomontara/environmental-monitoring,Diakses pada tanggal 10 Agustus 2012. 
bahwa melalui cara ini para pihak yang bersengketa dapat mengawasi prosedur penyelesaian sengketanya dan setiap penyelesaiannya didasarkan pada kesepakatan atau konsensus para pihak.

Negosiasi adalah cara yang pertama kali ditempuh manakala para pihak yang bersengketa. Negosiasi dalam pelaksanaannya memiliki dua bentuk utama, yaitu bilateral dan multilateral.Negosiasi dapat dilangsungkan melalui saluran diplomatik pada konferensi internasional atau dalam suatu lembaga atau organisasi internasional. Cara ini dapat pula digunakan untuk menyelesaikan setiap bentuk sengketa, apakah itu sengketa ekonomi, politik, hukum, sengketa wilayah, keluarga, suku, dan lainlain. Bahkan, apabila para pihak telah menyerahkan sengketanya kepada suatu badan peradilan tertentu, proses penyelesaiannya sengketa melalui negosiasi ini masih dimungkinkan utuk dilaksanakan.

Kelemahan utama penggunaan cara ini dalam menyelesaikan sengketa adalah :

a. Manakala kedudukan para pihak tidak seimbang. Salah satu pihak kuat, sedang pihak lain lemah. Dalam keadaan ini, pihak yang kuat berada dalam posisi untuk menekan pihak lainnya. Hal ini acap kali terjadi manakala dua pihak bernegosiasi untuk menyelesaikan sengketa di antara mereka. b. Proses berlangsungnya negosiasi acap kali lambat dan memakan waktu lama. Hal ini terutama dikarenakan permasalahan antarnegara yang timbul, khususnya masalah yang berkaitan dengan ekonomi internasional. Selain itu, jarang sekali adanya persyaratan penetapan batas waktu bagi para pihak untuk menyelesaikan sengketanya melalui negosiasi.

c. Apabila suatu pihak terlalu keras dengan pendiriannya. Keadaan ini dapat mengakibatkan proses negosiasi menjadi tidak produktif.

Segi positif dari negosiasi ini adalah sebagai berikut: ${ }^{64}$

a. Para pihak sendiri yang melakukan perundingan (negosiasi) secara langsung dengan pihak lainnya.

b. Para pihak memiliki kebebasan untuk menentukan bagaimana penyelesaian secara negosiasi ini dilakukan menurut kesepakatan mereka.

c. Para pihak mengawasi atau memantau secara langsung prosedur penyelesaiannya.

d. Negosiasi menghindari perhatian publik dan tekanan politik di dalam negeri.

e. Dalam negosiasi, para pihak berupaya mencar penyelesaian yang dapat diterima dan

64 Huala Adolf, 2004, Hukum Penyelesaian Sengketa Internasional, Bandung, Sinar Grafika.hlm.27. 
memuaskan para pihak, sehingga tidak ada pihak yang menang dan kalah tetapi diupayakan kedua belah pihak menang.

f. Negosiasi dimungkinkan dapat digunakan untuk setiap tahap penyelesaian sengketa dalam setiap bentuknya, apakah negosiasi secara tertulis, lisan, bilateral, multilateral, dan lainlain.

Penyelesaian

sengketa

sehubungan dengan pencemaran laut akibat tumpahan minyak yang terjadi pada kegiatan eksploitasi minyak lepas pantai PTTEP Australasia, hingga saat ini masih dalam proses negosiasi. Negara-negara yang terlibat dalam kasus pencemaran minyak ini adalah Australia, Indonesia dan Thailand.

PemerintahIndonesiamemegang peranan yang cukup penting dalam proses penyelesaian sengketa pencemaran minyak ini.Sebagaimana yang telah disampaikan sebelumnya bahwa akibat kasus pecemaran minyak ini, wilayah perairan Indonesia tepatnya yang berada di sekitar Provinsi Nusa Tenggara Timur mengalami pencemaran yang berdampak pada sektor perekonomian dan lingkungan laut masyarakat sekitar. Oleh karena itu, Pemerintah melakukan koordinasi dengan Pemerintah Daerah Provinsi Nusa Tenggara Timur.Koordinasi yang dilakukan dalam mengambil langkahlangkah yang berkaitan dengan pembuktian terjadinya pencemaran mulai dari survei hingga perhitungan perkiraan dampak pencemaran.
Berdasarkan

Peraturan

Presiden Nomor 109 Tahun 2006 tentang Penanggulangan Keadaan Darurat Tumpahan Minyak Di Laut, dalam Pasal 3, dinyatakan bahwa dalam rangka untuk keterpaduan penyelenggaraan penanggulangan keadaan darurat tumpahan minyak di laut tingkatan tier $3^{65}$, dibentuk Tim Nasional Penanggulangan Keadaan Darurat Tumpahan Minyak di Laut, yang selanjutnya disebut Tim Nasional. Tim Nasional yang dibentuk terdiri atas kementrian-kementrian terkait di Indonesia.

Tim Nasional diketuai oleh Menteri Perhubungan, Wakil Ketua, Menteri Negara LingkunganHidup, dan keanggotannya terdiri dari Menteri Energi dan Sumberdaya Mineral, Menteri Dalam Negeri, Menteri Luar Negeri, Menteri Kelautan dan Perikanan, Menteri Kesehatan, Menteri Kehutanan, Menteri Keuangan, MenteriHukumdanHakAsasiManusia, Panglima Tentara Nasional Indonesia, Kepala Kepolisian Negara Republik Indonesia, Kepala Badan Pelaksana Kegiatan Usaha Hulu Minyak dan Gas Bumi, Kepala Badan Pengatur Penyediaan dan Pendistribusian Bahan

65 Tier 3 adalah kategorisasi penanggulangan keadaan darurat tumpahan minyak yang terjadi di dalam atau di luar DLKP dan DLKR Pelabuhan atau unit pengusahaan minyak dan gas bumi atau unit kegiatan lain, yang tidak mampu ditangani - 9 - wilayah berdasarkan tingkatan tier2, atau menyebar melintasibatas wilayah Negara Kesatuan Republik Indonesia Lihat : Pasal 1 ayat 20, Peraturan Presiden No. 109 Tahun 2006, tentang Penanggulangan Keadaan Darurat Tumpahan Minyak di laut. 
Bakar Minyak dan Kegiatan Usaha Pengangkutan Gas Bumi melalui Pipa dan Gubernur, Bupati/Walikota yang sebagian wilayahnya mencakup laut.

Pemerintah Pusat juga melaksanakan negosiasi dengan Pemerintah Australia, hal tersebut dilakukan karena sumber pencemaran berada di dalam wilayah ZEE Australia.Selain itu, kerjasama Indonesia juga dilakukan karna kedua negara merupakan pihak-pihak yang dirugikan oleh pencemaran minyak PTTEP Australasia yang merupakan perusahaan swasta berasal Thailand.

Negosiasi yang dilakukan

oleh Pemerintah Indonesia dengan Australia merupakan implementasi MoU between the Government of Australia and Indonesia on Oil Pollution Preparedness and Response 1996, yang mengandung butir-butir kerjasama yang dapat diterapkan dalam menyelesaikan kasus pencemaran minyak tersebut, yaitu : kerjasama pertukaran informasi atas insiden pencemaran minyak di laut, inspeksi lapangan pada lokasi insiden minyak di laut yang sedang terjadi untuk kerjasama yang saling menguntungkan antar kedua belah pihak dan kerjasama tanggap darurat seperti mobilisasi personil, logistik dan peralatan lain yang dibutuhkan di dalam situasi darurat, dan lain-lain. Pemerintah Indonesia dan Australia bersama-sama melakukan pertukaran informasi, inspeksi dan kegiatankegiatan lain yang dibutuhkan dalam situasi darurat yang demikian.
Pemerintah Indonesia juga telah menyiapkan gugatan kepada Australia dan operator ladang minyak Montara PTTEP Australasia untuk memberi kompensasi atas kerugian yang dialami Indonesia akibat pencemaran tersebut. Tuntutan ganti kerugian tersebut didasarkan atas ketentuan yang terdapat padaInternational Convention On Civil Liability For Oil Pollution Damage 1969 (sekarang digantikan oleh CLC 1992), dimana Indonesia dan Australia telah meratifikasi konvensi tersebut, masing-masing Indonesia pada 6 Juli 1999 dan Australia pada 9 Oktober $1995^{66}$.Konvensi ini terdiri dari 21 pasal dan bertujuan untuk menjamin ganti rugi yang sesuai untuk pihakpihak yang menderita kerugian akibat pencemaran minyak di laut.

Berdasarkan hasil wawancara dengan Rayyanul M. Sangadji, proses negosiasi yang hingga saat ini berlangsung terjadi antara Indonesia secara PTTEP. Hingga saat ini, belum ada titik temu antara Indonesia dengan PTTEP Australasia mengenai pemberian ganti rugi yang dituntut oleh Indonesia.PTTEP Australasia pun tidak sepenuhnya hanya mendasarkan kewajiban ganti kerugian pada klaim yang diajukan oleh Pemerintah Indonesia. Sehingga, PTTEP melakukan investigasinya sendiri melalui tim yang telah dibentuk oleh PTTEP. Lamanya proses pemberian ganti rugi tersebut menyebabkan keresahan masyarakat Provinsi Nusa Tenggara Timur yang secara langsung 66 http://imo.amsa.gov.au/public/par 
merasakan dampak akibat pencemaran minyak Montara. ${ }^{67}$

Hingga saat ini belum ada titik temu antara pemerintah RI dengan pemerintah Australia.Pemerintah RI melalui Tim Advokasi Laut Timor (TALT) menegosiasikan ganti rugi atas dampak dari sektor perikanan, pertanian dan lingkungan di areal tersebut.Pencemaran terparah ada di kabupaten Rote Ndao merugikan 21.000 lebih warga pesisir di 48 desa disana.Negosiasi ini berlangsung sejak 27 Juli $2010^{68}$. Tidak hanya sektor perikanan yang mengalami dampak pencemaran minyak di laut Timor, Usaha budidaya rumput laut di pantai selatan Pulau Timor bagian barat NTT serta di pesisir Pulau Rote sampai ke Pulau Sabu, gagal total karena wilayah perairan pesisir yang menjadi usaha budidaya rumput laut, terkontaminasi minyak.

Pemerintah Indonesia dalam hal penuntutan ganti rugi yang dialami oleh masyarakat wilayah pesisir Kupang telah mengupayakan cara-cara yang bersifat diplomatis. Dimana dalam hal ini dilakukan karena Negara Indonesia menjunjung tinggi asas bertetangga yang baik serta mengusahakan implementasi dari Pasal 33 Piagam PBB untuk mengutamakan

67 Hasilwawancaradengan RayyanulM. Sangadji, Kepala Seksi Kerjasama Pemanfaatan Sumber Daya Laut, Sub Direktorat Perjanjian Kelautan Direktorat Perjanjian Kelautan Direktorat Perjanjian Politik, Keamanan dan Kewilayahan Kementrian Luar Negeri Republik Indonesia. Jakarta. 12 Mei 2011.

68 Kompas, 16 November 2010, Pemerintah Harus Siap Menggugat, Jakarta, hlm. 13. penyelesaian sengketa secara damai. Diplomasi dipilih karena telah menjadi satu bagian yang vital dalam kehidupan negara dan merupakan saran utama guna menangani masalah-masalah internasional. ${ }^{69}$

Diplomasi sebagai suatu cara komunikasi yang dilakukan oleh berbagai pihak termasuk negosiasi antara wakil-wakil yang sudah diakui atau yang diartikan pula sebagai perundingan-perundingan $^{70} \quad$ ketika sudah tidak memungkinkan untuk menemui titik terang maka salah satu pihak maupun kedua negara yang mengganggap perlu, dapat memilih jalur lain dalam penyelesaian sengketa. Berkaitan dengan kasus Montara, Indonesia dapat memilih jalur hukum yaitu melalui ITLOS.Bila semua jalur negosiasi dan diplomasi tertutup, jalur hukum internasional dibawah payung ITLOS terbuka untuk penyelesaian kasus tumpahan minyak di sumur Montara. $^{71}$

Apabila ITLOS dianggap terlalu dini untuk dipilih sebagai jalur penyelesaian sengketa, karena memang negara jarang sekali memilih ITLOS sebagai tempat penyelesaian sengketa, terbukti sejak entry into force (diantara tahun 1994 sampai dengan tahun 2006), hanya 13 kasus yang di

69 Sumaryo Suryokusumo, 2004, Praktik Diplomasi, Badan Penerbit IBLAM, Jakarta, hlm.1.

70 Sumaryo Suryokusumo, 2005, Hukum Diplomatik : Teori dan Kasus, Alumni, Bandung, hlm. 2.

71 Kompas, 18 Agustus 2012, Kasus Montar Berpeluang Pakai Payung ITLOS, Jakarta, hlm.14. 
tangani ITLOS ${ }^{72}$ di dalam UNCLOS masih memungkinkan adanya pilihan peradilan yang lebih fleksbel dan lebih diminati oleh negara-negara yaitu Arbitrase.

\section{KESIMPULAN}

Penyelesaian sengketa dalam Kasus Minyak Montara yang melibatkan Pemerintah Australia, Pemerintah Indonesia, Pemerintah Thailand dan pihak perusahaan sendiri yaitu PTTEP Australasia diselesaikan melalui proses Negosiasi. Sayangnya, hingga saat ini penyelesaian Kasus Minyak Montara ini belum mendapat penyelesaian yang memuaskan seluruh pihak.

\section{DAFTAR PUSTAKA}

Buku dan Literatur

Anil Kumar De, 2009, Environment and Ecology, New Age International, India.

Bambang Sutiyoso, 2008,Hukum Arbitrase dan Alternatif Penyelesaian sengketa, Gama Media, Yogyakarta.

Bernard Sipahutar, 2008, Penyelesaian

Sengketa Internasional Dalam Kerangka UNCLOS, Majalah hukum Forum Akademika, Fakultas Hukum Universitas Jambi.

72 Vaughan Lowe, 2007, The Interplay Between Negotiation and Litigation in International Dispute Settlement, Law of the Sea and Settlement of Dispute, Koninklijke Brill, Netherlands, hlm. 236.
Budislav Vukas, 2004, The Law of the Sea, Martinus NijhoffPublishers, Leiden.

Charles Okidi, 1998, Compendium of Judicial Decisions on Matters Related to Environment,UNEP/

Dutch Joint Project on Environmental Law and Institutions in Africa, Nairobi.

Ellie Louka, 2006, International Environmental Law : Fairness, Effectiveness and World Order, Cambridge University Press, New York.

Enid A. Marshall, 1988, Gill: The Law of Arbitration, Sweet \& Maxwell, London.

Eny Budi Sri Haryani, 2005, Makalah Pribadi Pengantar falsafah sains, IPB, Bogor.

Huala Adolf, 2004, Hukum Penyelesaian Sengketa Internasional, Bandung, Sinar Grafika.hlm.27.

Huala Adolf, 2006, Hukum Arbitrase Komersil Internasional, Raja Grafindo Persada, Jakarta.

J. G. Lammers, 2001, International Organzations and The Law of The Sea Documentary Yearbook, Martinus Nijhoff Publishers, Netherlands.

J. G. Merrills, 2005, "International Dispute Settlement", $4^{\text {th }}$ Edition, Cambridge University Press, United Kingdom.

J.G. Starke, 1988, Pengantar Hukum Internasional 2, EdisiKesepuluh, Sinar Grafika, Jakarta. 
M. Faisal Salam, 2007, Penyelesaian Sengketa Bisnis secara Nasional dan Internasional,,mandar maju, Bandung.

Maria Sumarjono, 2001, "Pedoman Pembuatan Usulan Penelitian", Gramedia Pustaka Utama, Jakarta.

Marquita K. Hill, 2004, Understanding

Environmental Pollution $2^{\text {nd }}$

Edition, Cambridge University Press, United Kingdom.

Marsudi

Triatmodjo, 1999. "Pertanggungjawaban Negara Terhadap Pencemaran Lingkungan Internasional”, Mimbar Hukum Universitas Gadjah Mada No.33/X/1999, Yogyakarta.

Melda Kamil Ariadno, 2007, Hukum Internasional Hukum Yang Hidup, Diadit Media, Jakarta. Phillipe Sands, 2003, Principle of International Environmental Law. Cambridge University Press, United Kingdom.

PriyatnaAbdurrasyid,2002,Pengusaha Indonesia Perlu Meningkatkan Minatnya Terhadap Arbitrase dan Alternatif Penyelesian Sengketa (Alternative Dispute Resolution ADR/ Arbitration), suatu Tinjauan, Jurnal Hukum Bisnis(edisiOktober-November 2002).

R. Soebekti, 1981, Arbitrse Dagang, Bina Cipta, Jakarta.

Rachmat usman, 2002, Hukum Arbitrase nasional, Grasindo, Jakarta, hlm. 18-19
Setiawan Y Sabungan, 2009 Pertanggungjawaban Negara dalam Perspektif Hukum Internasional, Fakultas Hukum Universitas Indonesia, Jakarta.

Siahaan N.H.T., 2004. Hukum lingkungan dan Ekologi Pembangunan, Erlangga, Jakarta.

Soerjono Soekanto \& Sri Mamudji, 2003, Penelitian Hukum Normatif Suatu Tinjauan, PT. Radja Grafindo Persada, Jakarta.

Sugeng Istanto, 2004, Bahan Kuliah Politik Hukum (Diktat Magister Hukum Program Pascasarjana UGM), Yogyakarta.

Sumaryo Suryokusumo, 2004, Praktik Diplomasi, Badan Penerbit IBLAM, Jakarta.

Sumaryo Suryokusumo, 2005, Hukum Diplomatik : Teori dan Kasus, Alumni, Bandung.

Thomas M. Pankratz 2001, Environmental Engineering Dictionary and Directions, Lewis Publishers, United States. Vaughan Lowe, 2007, The Interplay Between Negotiation and Litigation in International Dispute Settlement, Law of the Sea and Settlement of Dispute, Koninklijke Brill, Netherlands.

\section{Peraturan Perundang-undangan / Instrumen Internasional}

Declaration of The United Nations Conference on the Human Environment, Stockholm 1972 
Konvensi Perserikatan Bangsa-bangsa tentangHukumLaut,Departemen LuarNegeriDirektoratPerjanjian Internasional.

Peraturan Presiden No. 109 Tahun 2006, tentang Penanggulangan Keadaan Darurat Tumpahan Minyak di laut.

Treaty of Bayonne, 1866, Perancis.

United Nation Division for Ocean Affairs and The Law of The Sea Chronological lists of ratifications of, accessions and successions to the Convention andthe related Agreements, http://www.un.org/Depts/los/ reference_files/chronological_ list_of_ratifications.htm

United Nations, 2006, Reports of International Arbitral Awards, Trail Smelter Case (United States and Canada), 16 April 1938 and 11 March 1941, Volume III pp.1905-1982.

UU No 30 tahun 1999 tentang Arbitrase Dan Alternatif Penyelesaian Sengketa,

\section{Website/Internet}

Australia Embassy Indonesia, Montara Oil Spill, Media Release, 2 November 2009. Jakarta.

Cambridge Dictionary, www. c a mbridge.dictionary. org,Diakses pada tanggal 09 Agustus 2012.

Etang du Lanoux, http://en.wikipedia. org/wiki/\%C3\%89tang_du Lanoux,Diakses pada tanggal 16 Agustus 2012. http:/imo.amsa.gov.au/public/parties/ clc92protocol.html,diakses pada tanggal 5 April 2011.

Kompas, 16 November 2010, Pemerintah Harus Siap Menggugat, Jakarta, hlm. 13.

Kompas, 18 Agustus 2012, Kasus Montar Berpeluang Pakai Payung ITLOS, Jakarta, hlm.14. Montara Commission of Inquiry, www. montarainquiry.gov.au,Diakses pada tanggal 14 Agustus 2012.

PTTEP Australasia, 2012, The Montara Incident, http://www. au.pttep.com/our-responsetomontara/the-incident, Diakses pada tanggal 10 Agustus 2012.

PTTEP Australasia, Commission of Inquiry, http://www.au.pttep. com/our-response-to-montara/ commision-of-inquiry, Diakses pada tanggal 10 Agustus 2012

PTTEP Australasia, Environmental Monitoring, http://kiara.or.id/ content/view/1026/133/lang.id/, Diakses pada tanggal 10 Agustus 2012.

PTTEP Australasia, Montara Action Plan, http://www.au.pttep.com/ our-response-to-montara/actionplan, Diakses pada tanggal 10 Agustus 2012.

Sulphur dioxide/Sulfur dioksida Lihat : http://en.wikipedia.org/wiki/ Sulfur_dioxide, Diakses pada tanggal 18 Agustus 2012.

Tumpahan Minyak Perbatasan Harus Segera Diatasi, http://kiara. or.id/content/view/1026/133/ 
lang.id/, Diakses pada tanggal 12 Oktober 2011.

Wikipedia,Montara Oil Spill, www. wikipedia.com.Diakses tanggal 12 Juni 2010

William R. Slomanson, 2011, Fundamental Perspectives on International Law, Wardsworth Cengage Learning, United States, hlm. 659.

\section{Wawancara}

Hasil wawancara dengan Rayyanul M. Sangadji, Kepala Seksi Kerjasama Pemanfaatan Sumber Daya Laut, Sub Direktorat Perjanjian Kelautan Direktorat Perjanjian Kelautan Direktorat Perjanjian Politik, Keamanan dan Kewilayahan Kementrian Luar Negeri Republik Indonesia. Jakarta, 12 Mei 2011. 